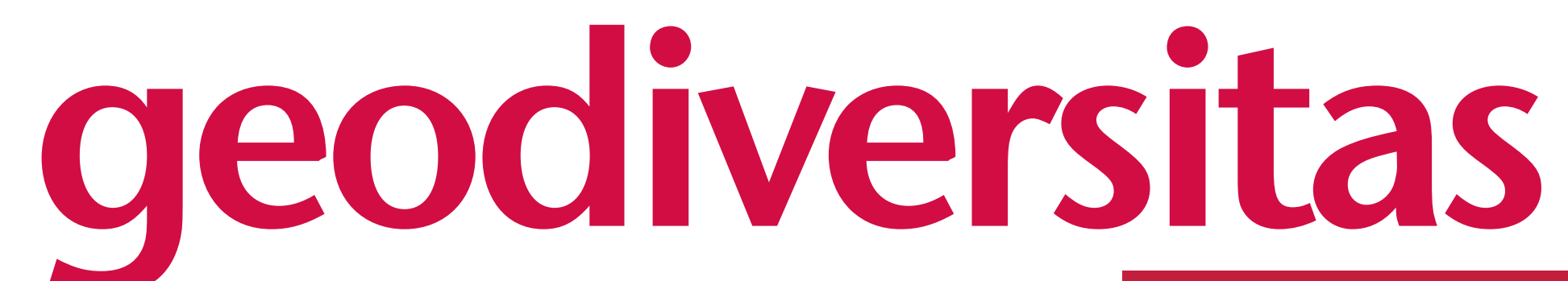

$2018 \cdot 40 \cdot 12$

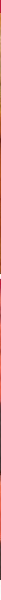

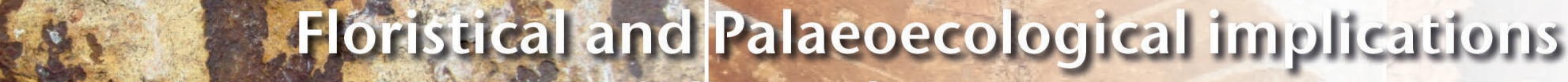
- 7 of the Early Cretaceous seguences of Krishina-Godavari Basin, East cuarst of Ifjelia

$6+1$

(1)

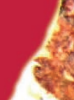

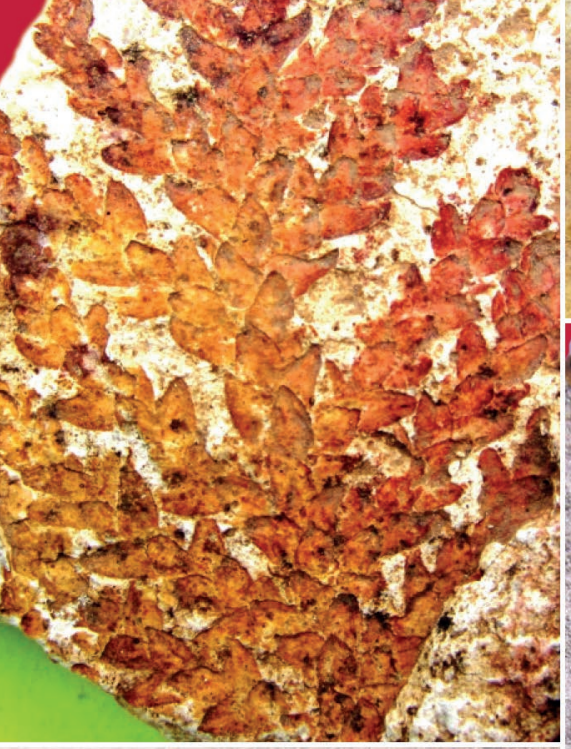

art. $40(12)$ - Publishied on 21 June 2018

www geediversitias, com

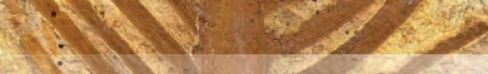 \\ - Chopparapu H. CHINNAPPA \& Ahitamroju RAJAWIKEANIHI
}

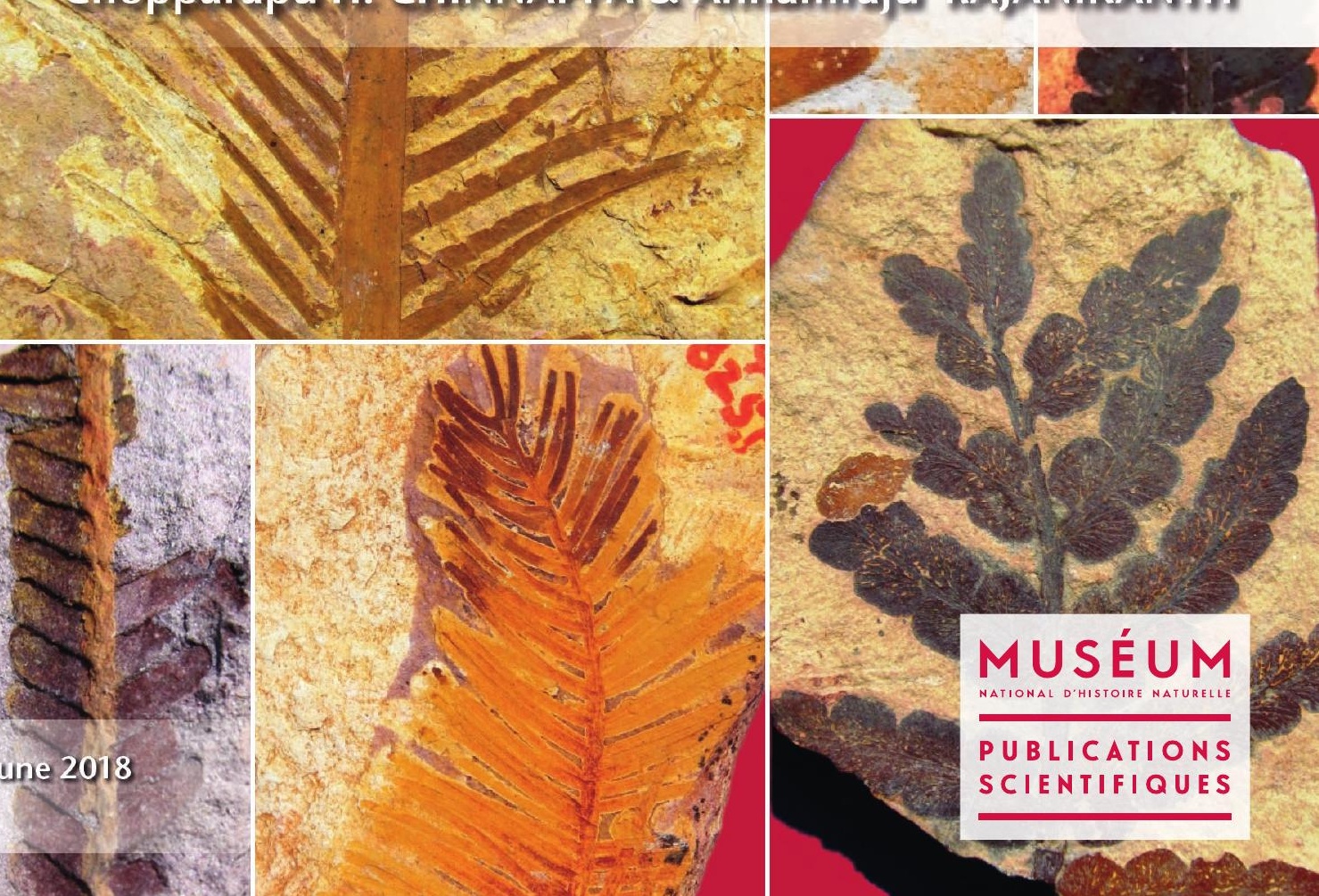


DiRECTEUR DE LA PUBLICATION: Bruno David,

Président du Muséum national d'Histoire naturelle

RÉdACTEUR EN CHEF / EDITOR-IN-CHIEF: Didier Merle

ASSISTANTS DE RÉDACTION / AsSISTANT EDITORS: Emmanuel Côtez (geodiv@mnhn.fr); Anne Mabille

Mise EN PAGE / PAGE LAYOUT: Emmanuel Côtez

COMITÉ SCIENTIFIQUE / SCIENTIFIC BOARD:

Christine Argot (MNHN, Paris)

Beatrix Azanza (Museo Nacional de Ciencias Naturales, Madrid)

Raymond L. Bernor (Howard University, Washington DC)

Alain Blieck (USTL, Villeneuve d'Ascq)

Henning Blom (Uppsala University)

Jean Broutin (UPMC, Paris)

Gaël Clément (MNHN, Paris)

Ted Daeschler (Academy of Natural Sciences, Philadelphie)

Bruno David (MNHN, Paris)

Gregory D. Edgecombe (The Natural History Museum, Londres)

Ursula Göhlich (Natural History Museum Vienna)

Jin Meng (American Museum of Natural History, New York)

Brigitte Meyer-Berthaud (CIRAD, Montpellier)

Zhu Min (Chinese Academy of Sciences, Pékin)

Isabelle Rouget (UPMC, Paris)

Sevket Sen (MNHN, Paris)

Stanislav Štamberg (Museum of Eastern Bohemia, Hradec Králové)

Paul Taylor (The Natural History Museum, Londres)

COUVERTURE / COVER:

Réalisée à partir de la Figure 5 de cet article/created from Figure 5 of this article.

Geodiversitas est indexé dans / Geodiversitas is indexed in:

- Science Citation Index Expanded (SciSearch $\left.{ }^{\circledR}\right)$

- ISI Alerting Services ${ }^{\circledR}$

- Current Contents ${ }^{\circledR} /$ Physical, Chemical, and Earth Sciences ${ }^{\circledR}$

- Scopus ${ }^{\circledR}$

Geodiversitas est distribué en version électronique par / Geodiversitas is distributed electronically by:

- BioOne ${ }^{\circledR}$ (http://www.bioone.org)

Les articles ainsi que les nouveautés nomenclaturales publiés dans Geodiversitas sont référencés par / Articles and nomenclatural novelties published in Geodiversitas are referenced by:

- ZooBank ${ }^{\circledR}$ (http://zoobank.org)

Geodiversitas est une revue en flux continu publiée par les Publications scientifiques du Muséum, Paris Geodiversitas is a fast track journal published by the Museum Science Press, Paris

Les Publications scientifiques du Muséum publient aussi / The Museum Science Press also publish: Adansonia, Zoosystema, Anthropozoologica, European Journal of Taxonomy, Naturae.

Diffusion - Publications scientifiques Muséum national d'Histoire naturelle

CP $41-57$ rue Cuvier F-75231 Paris cedex 05 (France)

Tél.: 33 (0)1 40794805 / Fax: 33 (0)1 40793840

diff.pub@mnhn.fr / http://sciencepress.mnhn.fr

(C) Publications scientifiques du Muséum national d'Histoire naturelle, Paris, 2018

ISSN (imprimé / print): 1280-9659/ ISSN (électronique / electronic): 1638-9395 


\section{Floristical and Palaeoecological implications of the Early Cretaceous sequences of Krishna-Godavari Basin, East coast of India}

Chopparapu H. CHINNAPPA

Andhra Loyola College, Vijayawada, Andhra Pradesh (India)

Annamraju RAJANIKANTH

Birbal Sahni Institute of Palaeobotany, 53 University Road, Lucknow, Uttar Pradesh (India)

Submitted on 13 October 2017 | accepted on 8 February 2018 | published on 21 June 2018

urn:Isid:zoobank.org:pub:2AE40BC8-437B-4B1B-A0E2-282EE3D876FD

Chinnappa C. H. \& Rajanikanth A. 2018. - Floristical and Palaeoecological implications of the Early Cretaceous sequences of Krishna-Godavari Basin, East coast of India. Geodiversitas 40 (12): 259-281. https://doi.org/10.5252/ geodiversitas2018v40a12. http://geodiversitas.com/40/12

\section{ABSTRACT}

The Early Cretaceous plant diversity and palaeoecology of the Krishna-Godavari Basin flora is studied. The study is based on the plant fossils collected by the authors during the recent years and published reports of past work. Nature and mode of preservation of the leafy fossils were considered to understand the vegetation relationship. Similarly, Nearest Living Equivalent method and palaeoecological information of diverse plant groups from the published sources, along with sedimentological inputs are adopted to draw the palaeoenvironnement. The results show that the flora was dominated by

KEY WORDS taphonomy, palaeoecology,
phytogeography, Early Cretaceous, Krishna-Godavari Basin.

\footnotetext{
MOTS CLÉS Flore,

taphonomie, paléoécologie phytogéographie, Crétacé inférieur, Bassin de KrishnaGodavari.
} bennettitaleans. The vegetation includes plant fossils from the parauto- to allo-chthonous sources. The association of the plant fossils with marine fauna indicates the vegetation was growing near to the sea. The phytogeographical correlation of the flora shows its similarity with that of Antarctica and Australia in the generic composition but greatly differ in specific composition. The composite flora indicates the prevalence of warm and humid conditions.

\section{RÉSUMÉ}

Analyse floristique et implications paléoécologiques des séquences du Crétacé inférieur du bassin de KrishnaGodavari, Côte Est de l'Inde.

La diversité et la paléoécologie de la flore du Crétacé inférieur du bassin de Krishna-Godavari sont étudiées. Ce travail exploite des récoltes récentes et des rapports préliminaires faits par les auteurs. La nature et le mode de préservation des feuilles fossiles sont étudiés afin de comprendre la relation entre les végétaux. Pour reconstituer les paléoenvironnements, des données sédimentologiques et des informations paléoécologiques sur des groupes variés ont été utilisées. Cette étude a aussi été complétée par une approche fondée sur la méthode actualiste. Les résultats montrent que la flore est dominée par les bennittitales. La végétation comprend des plantes d'origines parautochtone à allochtone. L'association de plantes à des éléments de faune marine indique un développement proche de la mer. L'analyse de corrélation phytogéographique montre des similitudes avec l'Antarctique et l'Australie dans sa composition générique, mais cette flore differe dans sa composition spécifique. Cette flore composite indique une prévalence de conditions climatiques chaudes et humides. 


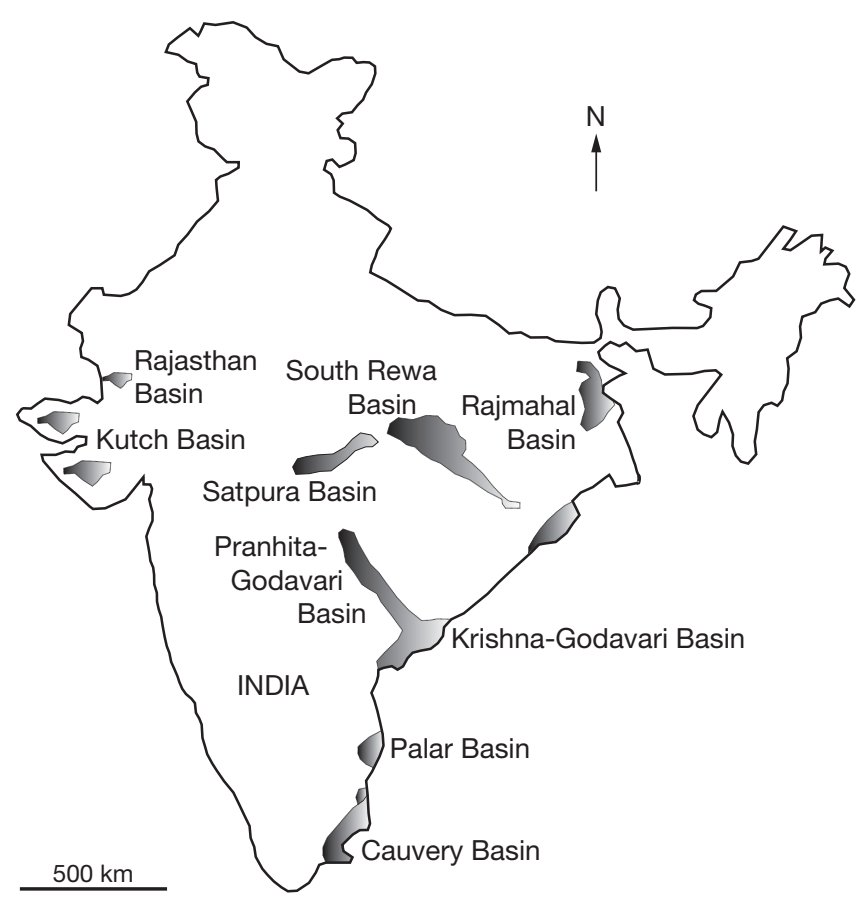

FIG. 1. - Locality map showing the fossil collection sites and the localization of the of the Krishna-Godavari Basin (East Coast of India).

\section{INTRODUCTION}

Fluvial-paralic sediments from the East Coast of India host some of the important Early Cretaceous (Neocomian-Aptian) fossil floras recording a range of vegetation types preserved in variety of depositional settings during the rifting event that fragmented eastern Gondwana. Plant fossil studies from these basins (e.g. Mehrotra et al. 2012; Rajanikanth \& Chinnappa 2016 and references therein) also show that sedimentary basins host information that contributes to our understanding of the southern Gondwana palaeogeography during the Early Cretaceous period (Rao \& Venkatachala 1972; Baksi 1977). Geographically and tectonically, these sedimentary units are grouped under 'Coastal Gondwanas', which are distributed in Cauvery (CV), Palar (PL), Krishna-Godavari (KG), PranhitaGodavari (PG) and Mahanadi (MH) basins (Fig. 1). The segmentation of these East Coast Indian sedimentary basins is owing to the intrinsic subcrustal distinction along the east coast. Each one of the subcrustal blocks behaved differently and mimicked the inherent subcrustal mosaic during the Gondwana period and carved out for itself an exclusive basin of Mesozoic-Cenozoic age. These basins, however, are separated by major tectonic elements. A major fault separates Bengal from Mahanadi; Visakhapatnam high separates Mahanadi from Krishna-Godavari; Nayudupeta high separates KrishnaGodavari from Palar; Chingleput high separates Palar from Cauvery Basins (Lal et al. 2009).

The Krishna-Godavari Basin (KG) has received much attention in recent times due to its high petroliferous/hydrocarbon source rock potential (Mehrotra et al. 2012). It is one of the most important petroliferous basins of India and occupies an area of $28000 \mathrm{~km}^{2}$ on shore and $24000-49000 \mathrm{~km}^{2}$ off shore (Rangaraju et al. 1993). The basin has been classified as a major intra-cratonic rift within Gondwanaland until the Early Jurassic period and it later transformed in to peri-cratonic rift basin (Biswas 1992). Sediments co-relatable to those of the Early Cretaceous ('Upper Gondwana') are exposed near the western and northwestern fringe of the Krishna (Budavada and Vemavaram formations) and Godavari (Golapalli and Raghavapuram formations) depressions. The sedimentation in these Cretaceous successions was linked with the faulting of basement blocks as a result of reactivation of NE-SW trending Precambrian faults (Biswas 1992).

Palaeobotanical studies from the Krishna-Godavari basin have been conducted for more than a century (Feistmantel 1879; Seward \& Sahni 1920; Sahni 1928; Baksi 1964, 1967, 1968; Bose \& Jain 1967; Jain 1968; Mahabale \& Satyanarayana 1979; Vagyani 1984, 1985; Vagyani \& Zutting 1986; Vagyani \& Jamane 1988; Pandya \& Sukh-Dev 1990; Pandya et al. 1990; Prasad \& Pundir 1999; Chinnappa et al. 2014, 2015; Chinnappa 2016). These studies were mostly restricted to the taxonomy; however, no attempt has been made to discuss the taphoceonosis, diversity and palaeoecological implications of the flora. Moreover, these studies were restricted either to macro- or microflora.

Macro- or microfloral investigations of ancient sediments can provide a partial picture; both must be considered together to get a complete picture of the vegetation (Chinnappa $\&$ Rajanikanth 2017). Therefore, the present study aims to analyze both the micro- and macrofloras from the Early Cretaceous sediments of Krishna-Godavari Basin, to provide a detailed account of taphoceonosis and to determine palaeoecological diversity patterns.

\section{GEOLOGICAL SETTING AND STRATIGRAPHY:}

The Krishna-Godavari (KG) Basin contains about $5 \mathrm{~km}$ of sediments recording several cycles of deposition, ranging in age from Late Carboniferous to Pleistocene. The basin came into existence following rifting along eastern continental margin of Indian craton in the Early Mesozoic (Sastri et al. 1973). Faults penetrating to the basement define the series of horst and grabens cascad down towards the ocean and are aligned NE-SW along Precambrian eastern Ghat trend (Sastri et al. 1973, 1981; Rao 2001). The first attempt to describe the geology of the basin was made by Blandford et al. (1856), followed by King (1880) who carried out detailed geological studies of the outcrops. Subsequently, these successions were studied in detail by several researchers (Sastri et al. 1973, 1981; Rao 1993, 2001; Lakshminarayana et al. 1992; Prabhakar \& Zutshin 1993; Raju \& Misra 1996; Prasad \& Pundir 1999; Lakshminarayana 2002). The Early Cretaceous Golapalli, Raghavapuram, Budavada and Vemavaram sediments are exposed towards the western and northwestern fringes of the basin (Fig. 2). These sediments were distributed in two depressions namely Godavari (Golapalli and Raghavapuram formations) and Krishna (Budavada and Vemavaram formations). Lakshminarayana et al. (1992) revised 


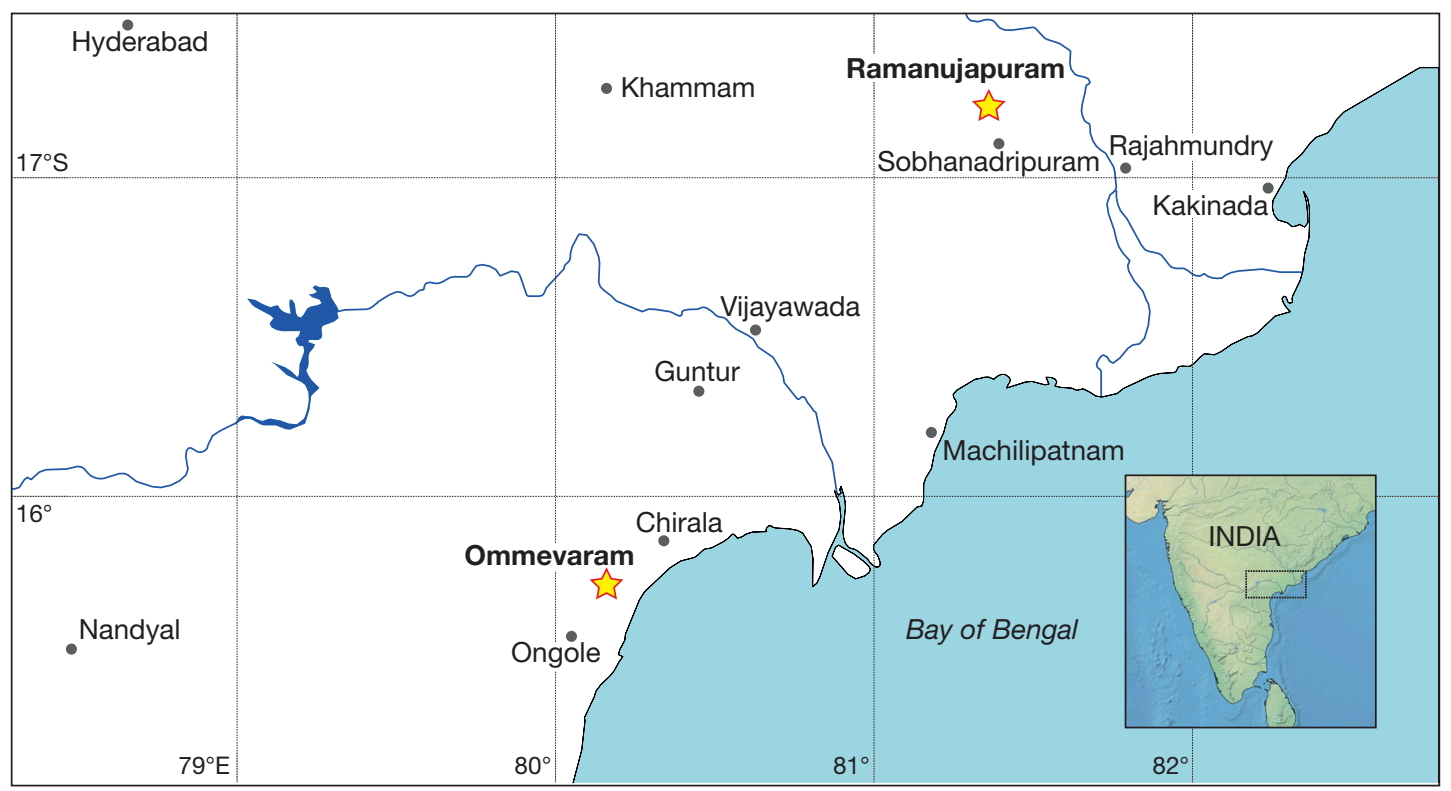

FIG. 2. - Map of the Krishna-Godavari Basin (East Coast of India; after Sastri et al. 1973) (map made with http://www.simplemappr.net).

the stratigraphy of these 'Upper Gondwana' sediments of the KG Basin and considered the Golapalli Formation under Kota Formation (Jurassic) at Musnuru, Nehrunagaram and Somavaram areas and similar rocks around Golapalli-Nuzividu areas were included under the Tirupati Formation (Late Cretaceous). However, Prasad \& Pundir (1999) and Rao (2001) treated these rocks under Golapalli Formation as originally identified by the King (1880). The tectonic framework and depositional environment of the basin was studied by Sastri et al. (1973, 1981), Baksi (1977), Vasudeva Rao \& Krishna Rao (1977), Venkatachala \& Sinha (1986) and Rao (2001).

The Early Cretaceous sediments exposed in the Godavari Depression are divided into the Golapalli, Raghavapuram and Tirupati formations (Fig. 3A). The Golapalli Formation comprises white to pale white and light brown sandstone with siltstone partings. The Raghavapuram Formation sandwiches between the Golapalli and Tirupati formations, characterized by white pale to reddish shale and red ferruginous claystone, light buff to grayish white, medium grained glauconitic sandstone. The Tirupati Formation overlies the Raghavapuram Formation and composed of purple red to light brown, medium grained sandstone.

The Early Cretaceous sediments exposed in the Krishna Depression are also divided into the Budavada, Vemavaram and Pavaluru formations (Fig. 3B). The sedimentary rocks of Budavada Formation is composed of sandstone. The Vemavaram Formation lies between the Budavada and Pavalur formations and is composed primarily of shale containing carbonaceous matter. The Pavalur Formation comprises of medium to coarse grained clay and lateritic sandstone and it is overlying by the Deccan intertrappeans (Rao 2001).

The Golapalli, Ragahavapuram and Tirupati formations are considered, equivalent to the Budavada, Vemavaram and Pavalur formations respectively (Sastri et al. 1973; Venkatachala \&
Sinha 1986; Venkatachala \& Rajanikath 1987). These formations are correlated with each other based on floral and faunal data (Sastri et al. 1973) Among these formations Golapalli, Raghavapuram, Budavada and Vemavaram are dated as the Early Cretaceous and Tirupati and Pavalur are Late Cretaceous based on mega and micro-floral and faunal evidences such as ammonites, brachiopods, lamellibranchs, fish scales and mammalian ribs (Spath 1933; Venkatachala \& Sinha 1986; Venkatachala \& Rajanikath 1987; Prasad \& Pundir 1999). The generalized lithostratigraphy of the basin is given in the Table 1 .

\section{MATERIAL AND METHODS}

Plant fossil material was collected from the mudstone succession of Raghavapuram Formation, exposed as a small hillock at about $1 \mathrm{~km}$ towards the South East of the village Ramanujapuram (17²13'27”N, 8119'11”E), near Jangareddigudam, West Godavari District, Andhra Pradesh, India (Fig. 2). The fossiliferous section is characterized by white pale to reddish mudstone/shale and red ferruginous claystone, and light buff to grayish white, medium grained glauconitic sandstone. Plant fossils were preserved in pale-reddish mudstones/earthy shales (Fig. 3A). The plant fossils were also collected from the Vemavaram Formation, exposed at road cutting near about $0.5 \mathrm{~km}$ towards the North West and North East of the village Ommevaram (15\%41'17”N, 8009'01”E), near Ongole, Prakasam District, Andhra Pradesh, India (Fig. 2). These plant fossils were preserved in shale (Fig. 3B). The fossil leaves were preserved as impressions, and cuticules have not been recovered. Examination was done using an Olympus SZH 10 stereo dissecting microscope. All specimens were photographed with Canon SX 150 IS digital camera using either polarized light or low angle lighting to reveal surface details. 
TABLE 1. - Lithostratigraphy and ages of the various lithounits in the KG Basin (data from Sastri et al. 1973; Lakshminarayana et al. 1992; Prasad \& Pundir 1999) .

\begin{tabular}{|c|c|c|c|}
\hline Group & Formation & Lithology & Age \\
\hline \multicolumn{4}{|c|}{ Recent alluvium } \\
\hline \multirow[t]{2}{*}{ Tertiary } & Rajahmundry & $\begin{array}{l}\text { Red, feldspathic, ferruginous, laterized, } \\
\text { crossbedded and conglomeratic sandstone }\end{array}$ & Miocene-Pliocene \\
\hline & Infra-Inter-Trappeans & Basaltic lava & $\begin{array}{l}\text { Late Cretaceous-Early } \\
\text { Paleocene }\end{array}$ \\
\hline \multicolumn{4}{|c|}{$\sim$ Unconformity $\sim$} \\
\hline \multirow[t]{4}{*}{ Upper Gondwana } & Tirupati/Pavalur & $\begin{array}{l}\text { Purple red-light brown sandstone/clay and } \\
\text { caleritic sandstone }\end{array}$ & Late Cretaceous \\
\hline & $\begin{array}{l}\text { Raghavapuram/ } \\
\text { Vemavaram }\end{array}$ & $\begin{array}{l}\text { White pale-reddish earthy shale, red } \\
\text { ferruginous claystone, light buff-grayish } \\
\text { white glauconitic sandstone/shale } \\
\text { containing carbonaceous matter }\end{array}$ & Early Cretaceous \\
\hline & \multicolumn{3}{|c|}{$\sim$ Unconformity $\sim(n$} \\
\hline & Golapalli/Budavada & $\begin{array}{l}\text { White-pale white and light brown sandstone } \\
\text { with siltstone partings/sandstone }\end{array}$ & Early Cretaceous \\
\hline \multicolumn{4}{|c|}{$\sim$ Unconformity $\sim \sim$} \\
\hline Lower Gondwana & Chintalapudi/Kamthi & $\begin{array}{l}\text { Coarse grained feldspaathic sandstone, } \\
\text { alternating calcareous claystone }\end{array}$ & Permain \\
\hline \multicolumn{4}{|c|}{$\sim$ Unconformity/Fault $\sim$} \\
\hline Proterozoic & Khondalite & Igneous and metamorphic rocks & Precambrian \\
\hline
\end{tabular}

To isolate spores and pollen, sediments from all the localities that have yielded macrofossils were also treated with hydrochloric, hydrofluoric and nitric acid ( $\left.\mathrm{HCl}-\mathrm{HF}-\mathrm{HNO}_{3}\right)$ and sieved (mesh width $25 \mathrm{~mm}$ ). However, only samples from the Raghavapuram were productive. The slides were studied under an Olympus BH 2 microscope, fitted with a digital camera. All samples and slides (BSIP 40156-40192 and 40243-40285) are deposited in the repository of Birbal Sahni Institute of Palaeobotany for future reference.

The taxonomic affinities at family level of the spore/pollen obtained are after Ramanujam \& Rajeshwar Rao (1979). Similarly, the taxonomic affinity of the pteridophytic fronds at family level follows Harris (1969) and Barbacka \& Bodor (2008). However, the taxonomic affinities at family level are not certain for many gymnosperm taxa; many of these taxa could be related to more than one family. Macro-and microfloral species diversity was analysed separately by considering the total number of taxa known in the flora. The reports of the present study and previous studies are taken into consideration for this purpose. The taxonomic diversity of the flora is presented in pie diagrams as simple percentage representation of each group (at order level), generated by using MS Excel. Similarly, the abundance of the various plant taxa was calculated by counting the number of samples for the given taxa. The difference between the micro-and macroflora is explained with regard to taphonomy and natural variations.

\section{COMPOSITION OF THE FLORA}

The synthesis of macro-and microflora from the Early Cretaceous sequences of the Krishna-Godavari Basin shows that the flora is diverse and composed of bryophytes, pteridophytes, gymnosperms and angiosperms (Appendices 1, 2). The diversity and abundance patterns of these plant groups, however, are not consistent between the macro- and microfloras.

\section{BRYOPHYTES}

Macrofossils belonging to this group have not (yet) been recorded to date. In contrast, spores are well represented and constitute members of Anthocerataceae (Foraminisporis Krutzsch), Sphaerocarpaceae (Aequitriradites Delcourt \& Sprumont, emend. Cookson \& Dettmann and Coptospora Dettmann) and Reillaceae (Cooksonites Pocock, and Staplinisporites Pocock) (Ramanujam 1957; Kar \& Sah 1970; Venkatachala \& Sinha 1986; Prasad \& Pundir 1999; Mehrotra et al. 2012). The qualitative and quantitative composition of the group is less when compared to the other spore producing plants such as pteridophytes (Appendix 2).

\section{PTERIDOPHYTES}

Pteridophytes are represented in both macro-and microfloras, especially the microflora. Fossil fronds belong to the Marattiaceae, Osmundaceae, Gleicheniaceae and Dicksoniaceae and a few Sphenopteris Sternberg type fossils of unknown affinity were recorded (Fig. 4). Many families such as the Lycopodiaceae, Selaginellaceae, Matoniaceae, Schizaeaceae, Marsileaceae, Cyatheaceae and Polypodiaceae are only represented in the microflora. Among these families, the Schizaeaceae and Cyatheaceae display highest species diversity (Fig. 5). The Schizaeaceae include six genera encompassing a total of 17 species and Cyatheaceae constitute 23 species in eight genera (Appendix 2). A few more pteridophytic spore taxa, cannot be assigned to any family with certainty and they are placed in pteridophyte incertae sedis (Appendix 2). 

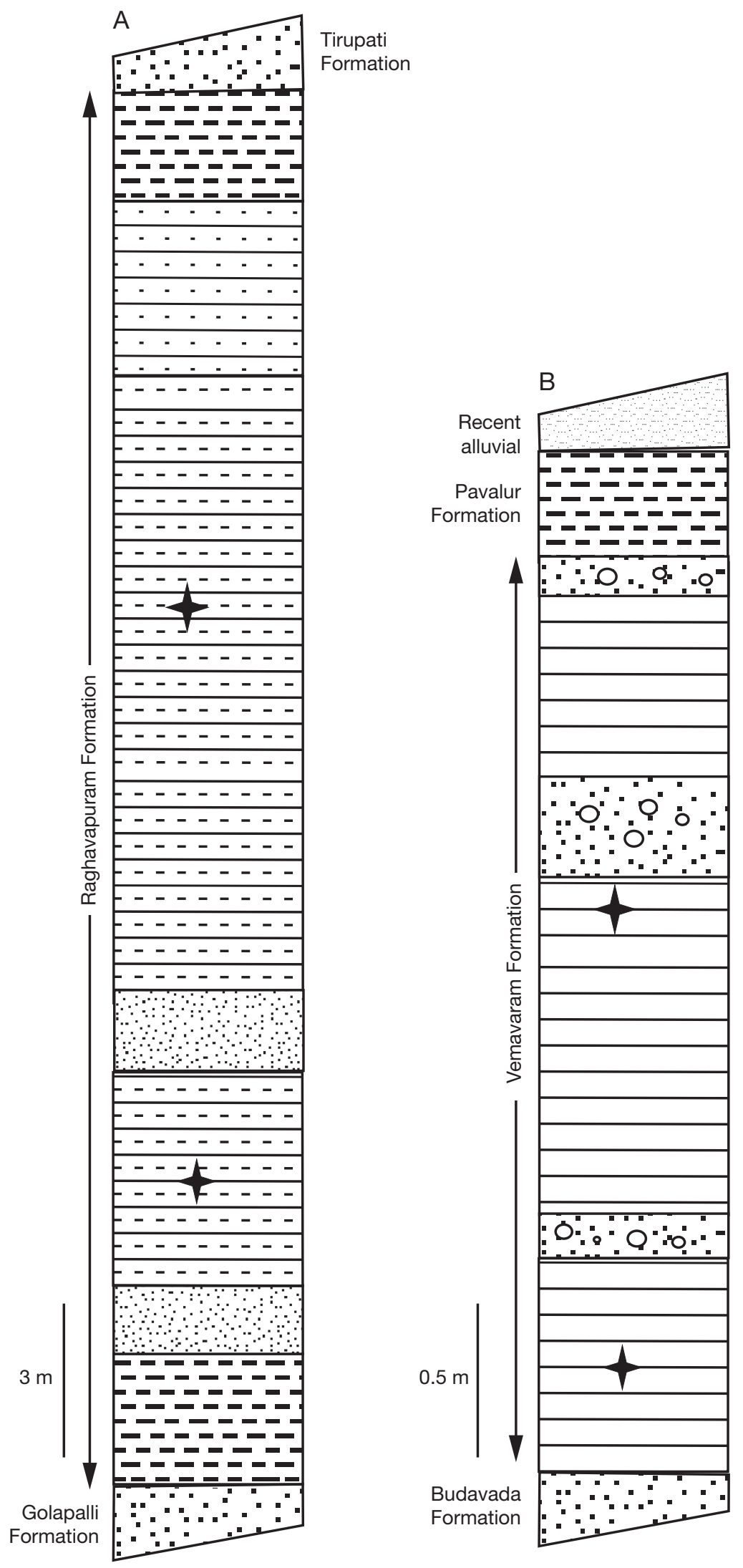
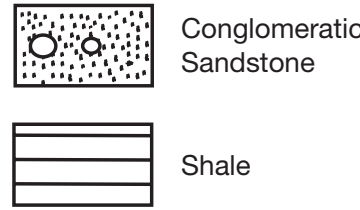

Shale

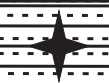

Fossiliferous

Bed

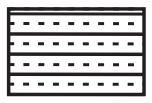

Sandy shale

드늠] Claystone

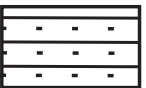

Silty sandstone

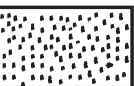
Sandstone 
Marattiaceae fossil leaves are rare in the Krisha-Godavari flora, there are only a couple of reports of these fern fronds from the Golapalli Formation (Feistmantel 1876, 1877). The family is represented by a single genus with one species: Marattiopsis macrocarpa (Oldham \& Morris) Seward and Sahni. Spores related to this family have not been reported.

Macrofossils of Osmundaceae are represented by five species belonging to two genera: Cladophlebis Brongniart and Todites Seward emend. Harris (Appendix 2). Within the two genera, the former is known from the both Raghavapuram and Golapalli formations but latter is known only from Golapalli Formation (Pandya \& Sukh-Dev 1990; Prasad \& Pundir 1999). From the Vemavaram Formation the macrofossils of the Osmundaceae are altogether absent. All the species were preserved as pinnae fragments, whole fronds are unknown. Pinnules were well preserved with a distinct venation pattern.

The Krishna-Godavari flora includes spores related to Osmundaceae in four genera - Baculatisporites Pflug \& Thomson, Biretisporites (Delcourt \& Sprumont) Delcourt et al., Osmundacidites Couper, and Todisporites Couper, altogether with five species (Appendix 2). Osmundacidites type of spore is known as produced by Todites (Naugolnykh 2002). Although, the relationship of rest of the spores with Cladophlebis and Todites is not known, their spores are considered to be produced by Osmundaceae members (Kustatscher et al. 2010).

Gleicheniaceae includes a single genus, Gleichenia Smith, with two species (Appendix 1), which are reported from the Golapalli Formation (Feistmantel 1876; Prasad \& Pundir 1999). Microfossils are represented by three genera: Gleicheniidites Ross, Ornamentifera Bolkhovitina and Plicifera Bolkhovitina, altogether with seven species.

From Dicksoniaceae a single genus Onychiopsis Yokoyama, represented by a single species (Appendix 1) was found from the Golapalli Formation (Prasad \& Pundir 1999). The genus corresponds well with the living fern Onychium Kaulf in its morphology and spore morphology. Only a fragmentary specimen is known in the studied flora, not enough morphological details were observed hence the specimen is placed under the comparative form O. psilotoides Stokes \& Webb on the basis of gross morphological similarity (Prasad \& Pundir 1999). A number of spore genera are known to originate from Cyatheaceae/Dicksoniaceae and they are the most abundant in the present microflora (Appendix 2).

\section{GYMNOSPERMS}

Gymnosperms are important components of the Mesozoic floral ecosystems, dominating until the Late Cretaceous (Vakhrameev 1991). However, they started to decrease in their diversity and abundance, with the appearance of angiosperms in the Early Cretaceous and their subsequent expansion in the Late Cretaceous (McLoughlin 2001; Friis et al. 2011). In the Krishna-Godavari flora, the gymnosperms constitute a major share.

\section{PTERIDOSPERMS}

Pteridosperms are rare components in the Early Cretaceous Krishna-Godavari flora and are represented by two genera:
Thinnfeldia Ettingshausen and Pachypteris (Brongniart) Harris with single species in each genus (Appendix 1). Of the two genera the former was reported from the Vemavaram and Raghavapuram formations (Feistmantel 1879; Baksi 1968; Chinnappa 2016) and the latter is known from the Vemavaram and Golapalli formations (Feistmantel 1876; Pandya \& Sukh-Dev 1990)

Traditionally, Thinnfeldia type leaves reported from the early Cretaceous of India were variously assigned to Dicroidium Gothan and Thinnfeldia Ettingshausen (Feistmantel 1879, 1882; Lele 1962; Rao \& Lele 1963; Baksi 1968; Jain 1968). Many of these specimens were originally described under Thinnfeldia by Feistmantel (1879, 1882). Later, however, Lele (1962) and Rao \& Lele (1963) re-evaluated these fossil leaf types and transferred them from Thinnfeldia to Dicroidium. While doing so, Lele (1962) and Rao \& Lele (1963) also considered the similar fossil leaves were also in Dicroidium despite their origin from the Early Cretaceous succession and morphological variations (Townrow 1957). Subsequently, Baksi (1968) and Jain (1968) also placed the leaf fossils resembling Thinnfeldia in Dicroidium instead. Dicroidium is characterized by dichotomized rachis with frequent sphenopteroid to taeniopteroid venation in the pinnules whereas Thinnfeldia lacks the dichotomized rachis and shows frequent odontopteroid and alethopteroid venation. Further, Thinnfeldia is considered as geologically younger (Jurassic) than the Dicroidium (Triassic). Chinnappa (2016) has considered the leaves described under Dicroidium from the Early Cretaceous sediments of India under Thinnfeldia based on the morphology and stratigraphic distribution. Recently, Cleal \& Rees (2003) considered Thinnfeldia as taxonomic synonym of Pachypteris; nevertheless, we believe that the Indian specimens referred to Thinnfeldia needs a critical re-examination before considering them under Pachypteris.

\section{CYCADALEANS}

Foliage resembling that of modern-day cycads has long presented palaeobotanists with major problems, especially when dealing with foliage lacking cuticles. Taeniopteris Brongniart leaves are one such type that has a poorly understand systematic position (Pott \& Launis 2015; Van Konijnenburg-Van Cittert et al. 2017; Chinnappa \& Rajanikanth 2017). The affinity of leaves of this type can be clarified only when they associated with reproductive structures or preserved with cuticle (Cleal \& Rees 2003; Pott \& Launis 2015; Van Konijnenburg-Van Cittert et al. 2017). However, in the studied locality the leaves are known only as imprints, with no cuticles or associated reproductive structures having been found to date. Leaves of this type are here represented by a single species Taeniopteris spatulata McClelland known from all the three litho-units: Vemavaram (Feistmantel 1879), Raghavapuram (Baksi 1968; Chinnappa 2016) and Golapalli (Feistmantel 1876; Pandya \& Sukh-Dev 1990; Prasad \& Pundir 1999). Because the present leaves are preserved as impressions and there is a large uncertainty regarding the systematic affinity of the genus, we placed them under incertae sedis within the gymnosperms as suggested by Cleal \& Rees (2003) and Pott \& Launis (2015). 

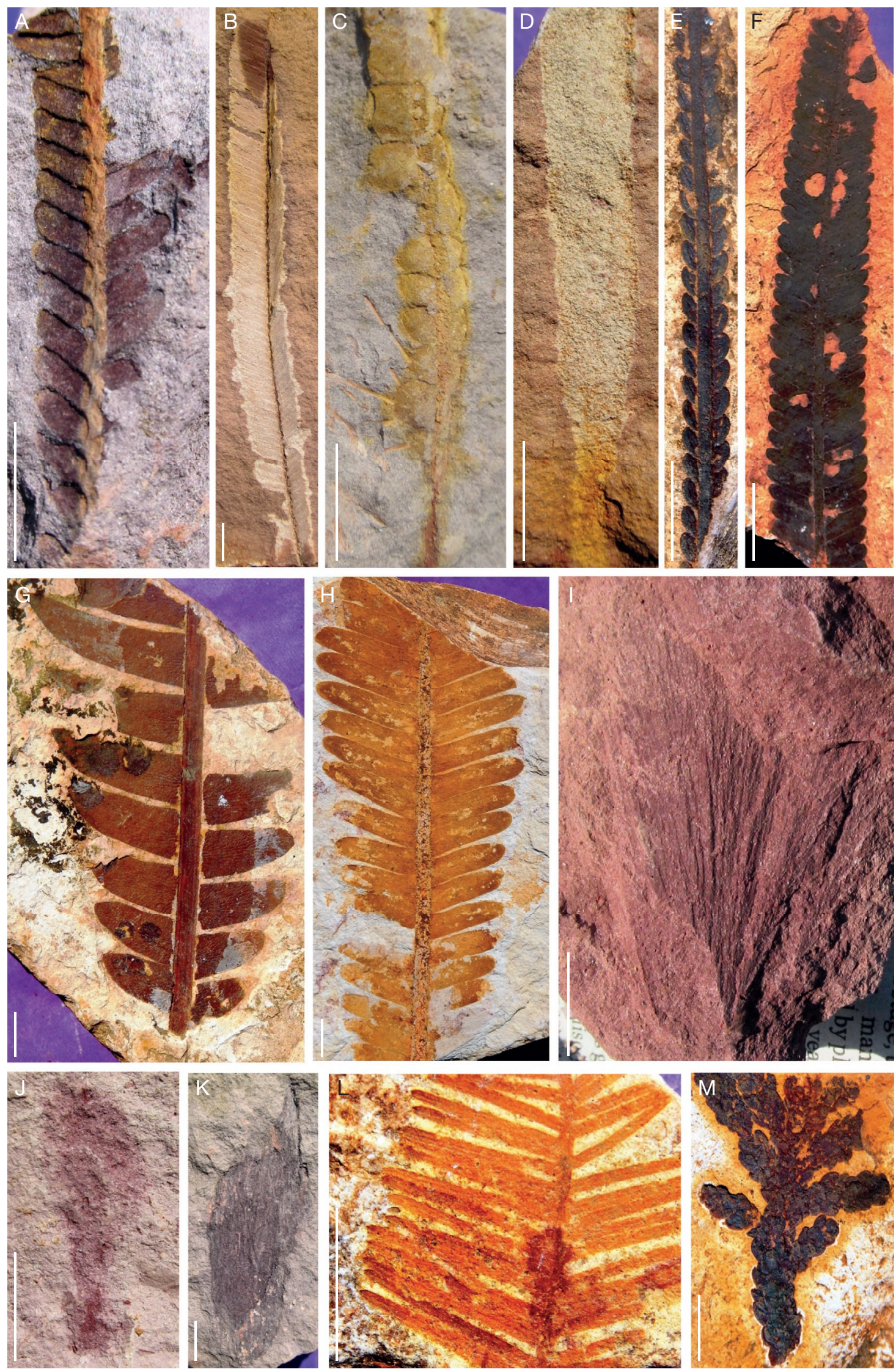

FIG. 4. - Plant material preserved from the KG basin: A, Ptilophyllum cutchense (Morris) Bose \& Kasat; B, Ptilophyllum acutifolium (Morris) Bose \& Kasat; C, Anomozamites sp.; D, Taeniopteris sp.; E, Otozamites vemavaramensis Bose \& Jain; F, Ptilophyllum rarinervis (Feistmantel) Bose \& Kasat; G, Dictyozamites ommevaramensis Chinnappa, Rajanikanth \& Rao; H, Dictyozamites feistmantelii Bose \& Bano; I, Ginkgo sp. J Pityospermum godavarianum Chinnappa, Rajanikanth \& Rao; K Araucarites raghavapurensis Chinnappa, Rajanikanth \& Rao; L, Elatocladus loyolii Chinnappa, Rajanikanth \& Rao; M, Brachyphyllum sehoraensis Bose \& Maheshwari. Scale bars: $1 \mathrm{~cm}$. 

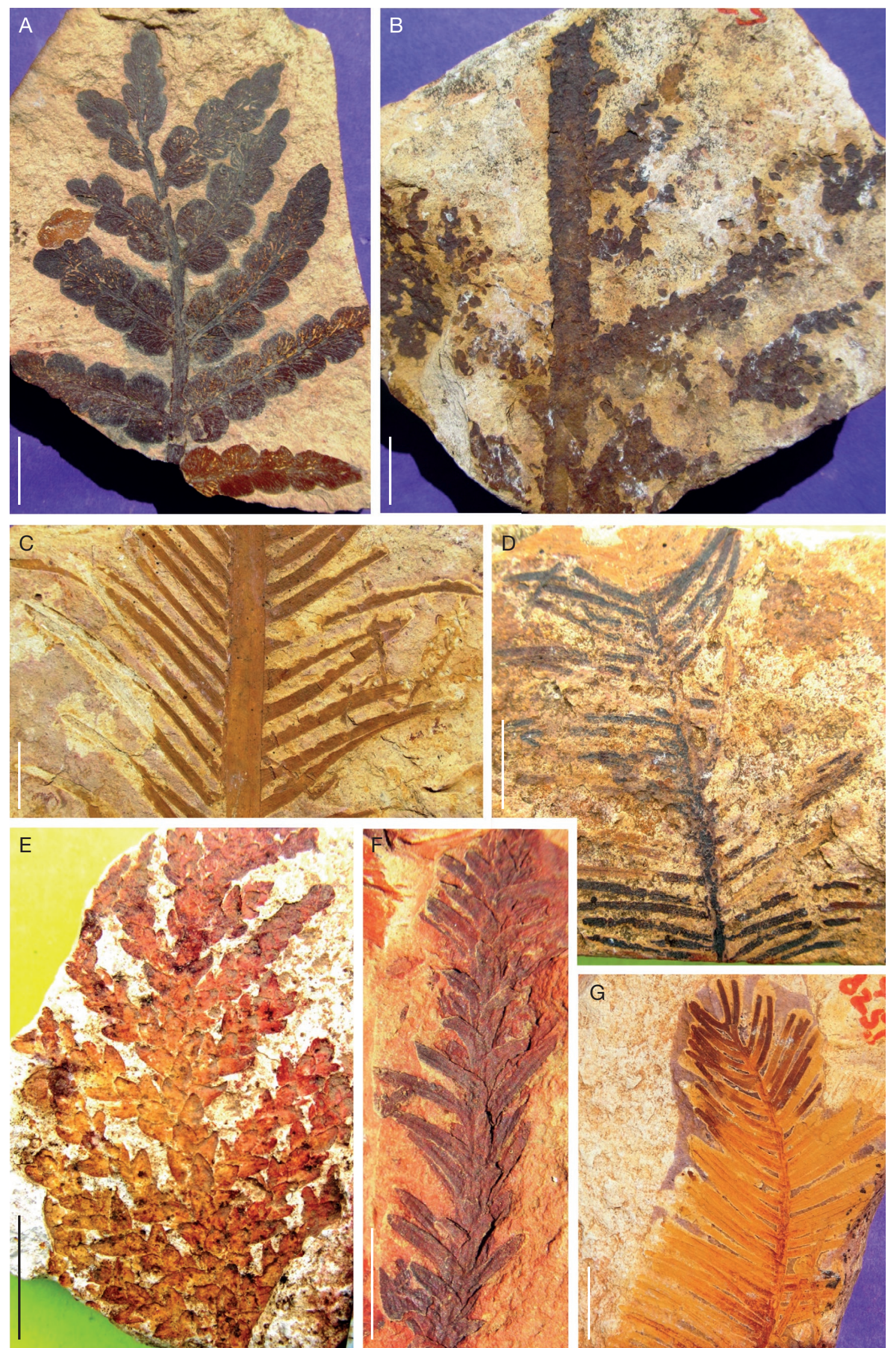

FIG. 5. - Plant material preserved from the KG basin: A, Thinnfeldia vemavaramensis (Feistmantel) Chinnappa, Rajanikanth \& Rao; B, Brachyphyllum expansum (Sternberg) Seward; C, Pterophyllum footeanum Feistmantel; D, Elatocladus loyolii Chinnappa, Rajanikanth \& Rao; E, Pagiophyllum ommevaramensis Chinnappa, Rajanikanth \& Rao; F, Pagiophyllum cf. rewaensis Bose \& Sukh-Dev; G, Elatocladus loyolii. Scale bars: $1 \mathrm{~cm}$. 


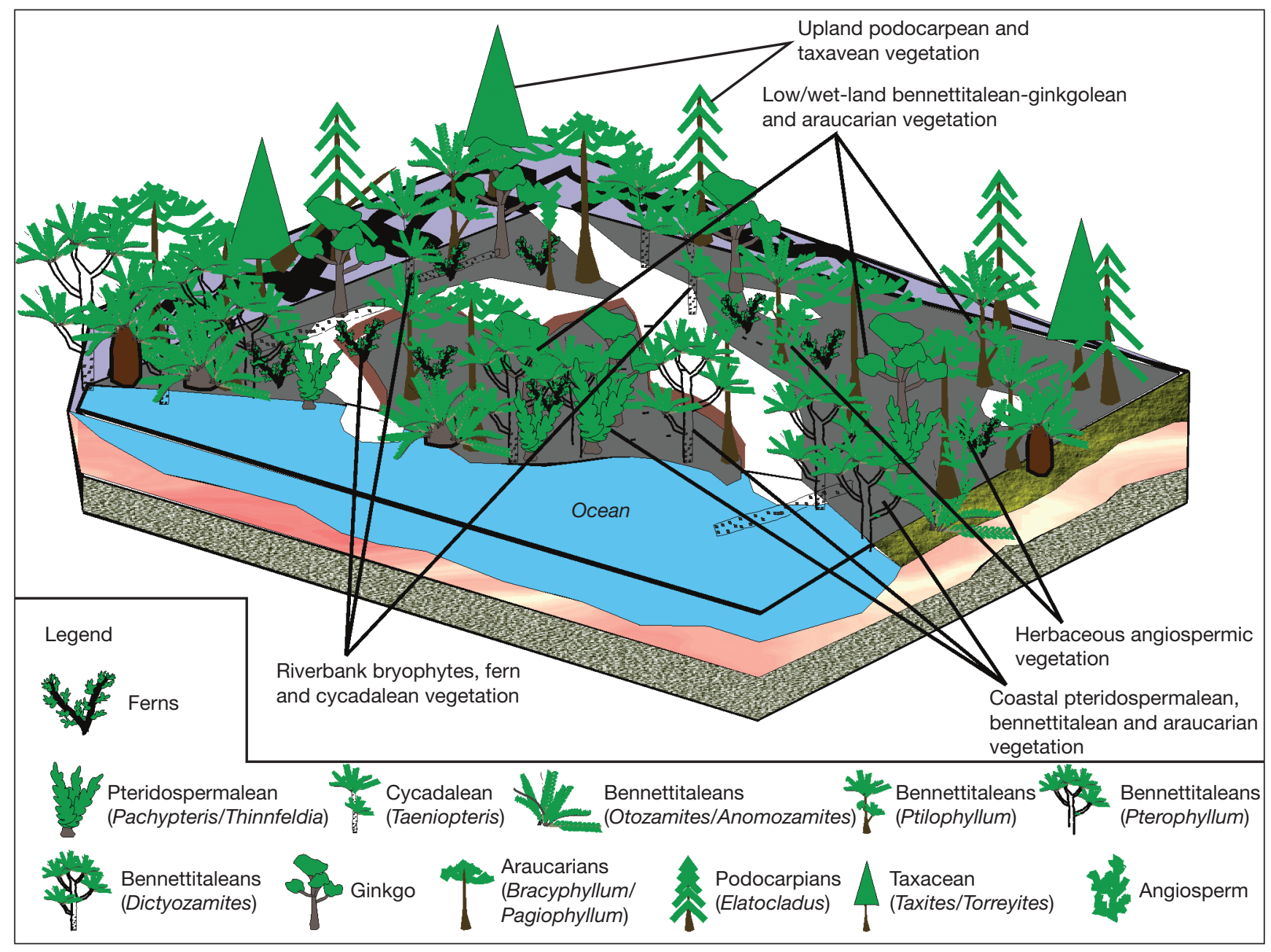

FIG. 6. - The macrofloral diversity of the various plant groups in the Krishna-Godaveri Basin (East Coast of India).

\section{BENNETTITALEANS}

Bennettitalean leaves are most common in the Early Cretaceous Krishna-Godavari floras. Six genera: Anomozamites Schimper, Dictyozamites Oldham, Otozamites Braun, emend. Watson \& Sincock Pterophyllum Brongniart, Ptilophyllum Morris, and Dictyozamites Oldham were identified following the criteria given by Harris (1969) and Watson \& Sincock (1992).

Among these, Ptilophyllum fronds are the most common and widely distributed throughout all the three formations. Twelve species have been reported to date (Appendix 1), of which six are assigned to the comparative forms such as $P$. distans (Feistmantel) Bose \& Kasat, P. cf. institacallum Bose, $P$. amarjolense (Bose) Bose $\&$ Kasat, $P$. cf. gladiatum Bose \& Sukh-Dev, P. cf. horridum (Roy) Bose \& Kasat, P. cf. jabalpurense (Jacob \& Jacob) Bose \& Kasat (Appendix 1). Ptilophyllum acutifolium (Morris) Bose \& Kasat, and P. cutchense (Morris) Bose \& Kasat are most common in the studied plant assemblage. The identification of these species based only on the gross morphology. To date, cuticle has not been prepared from the Krishna-Godavari floras. Dictyozamites and Otozamites leaves are nearly as common as Ptilophyllum, but being mostly found in Vemavaram Formation (Feistmantel 1879; Chinnappa et al. 2015; Chinnappa 2016). These genera are represented by six species each (Appendix 1). Specimens belonging to Dictyozamites are rarely observed in the Raghavapuram and Golapalli formations and are represented in the flora by only a few fragmentary leaves (Baksi 1964; Pandya \& Sukh-Dev 1990). Otozamites is altogether absent from Golapalli Formation. The other bennettitalean foliages such as Anomozamites and Pterophyllum are comparatively less common. From each of these genera three species are documented (Appendix 1). The former is reported only from the Vemavaram, whereas the latter known from all the three areas (Feistmantel 1879; Chinnappa et al. 2015).

Little fertile bennettitalean material has been described from Gondwana floras to date (Cantrill 2000). However, a few specimens of Cycadolepis Saporta and Williamsonia Carruthers are present in the flora studied here (Seward \& Sahni 1920; Baksi 1968; Pandya \& Sukh-Dev 1990). Cycadolepis is generally presumed to represent the bract from the base of a female cone (Cantrill 1997a), while Williamsonia is considered to be a bennettitalean strobilus (Harris 1969) and they are represented here by two species each (Appendix 2). 


\section{GiNKGOALEANS}

Members of the Ginkgoales are most commonly encountered from the Krishna-Godavari Basin; however, they are restricted to the Raghavapuram Formation (Feistmantel 1877; Baksi 1967, 1968; Vagyani 1985; Chinnappa et al. 2015). This indicates that the plants were growing in abundance in the basin. Mesozoic leaves resembling modern ginkgo leaves are usually placed in the genus Ginkgo Linnaeus or Ginkgoites Seward. Seward (1919) and Tralau (1967) maintained the distinction between the two genera based on the nature of lobes in leaf. Leaves of Ginkgo are divided into two or more lobes by shallow notches which never reach the basal part of the lamina, whereas in Ginkgoites leaves are deeply and symmetrically divided into narrow segments (Tralau 1967). However, Harris \& Millington (1974) considered these distinctions are not applicable in reality as trees of Ginkgo biloba can produce many deeply divided leaves. Chinnappa (2016) merged all the Indian specimens previously described under Ginkgoites with Ginkgo, thus considering the recommendations of Harris \& Millington (1974). The genus here represented by four species which gives $5 \%$ of species diversity in the Krishna-Godavari basin (Appendix 1). The pollen grain Ginkgocycadophytus Samoilovitch (with two species) is the only possible genus represented in the Krishna-Godavari flora probably produced by ginkgoaleans (Appendix 2).

\section{CONIFERALEANS}

Although the abundance of the conifer remains is low in the flora they show considerable taxonomic diversity (Appendices 1, 2). Eight genera are represented by macroremains: Araucarites Presl, Brachyphyllum Brongniart, Pagiophyllum Heer, Elatocladus Halle, Torreyites Seward, Conites Sternberg, Harrisiophyllum Pant, Srivastava \& Pant, and Pityospermum Nathorst. The number of species identified within each genus is given in Appendix 1.

The genus Araucarites, belonging to the Araucariaceae, includes four species (Appendix 1) and is distributed to all the three formations: Vemavaram (Feistmantel 1879) Raghavapuram (Chinnappa et al. 2015) and Golapalli (Feistmantel 1876). The genus Araucarites is based on an ovuliferous cone scale that resembles those of recent Araucariaceae. Ovuliferous scales with a single ovule/seed and a free distal ligule are indicative of its affinity with the Araucariaceae (Cleal \& Rees 2003). Our specimens of Araucarites are preserved with a woody bract and a centrally fused seed mark.

Leafy axes belonging to Brachyphyllum and Pagiophyllum are common among the conifer remains in the Krishna-Godavari flora (Sahni 1931; Baksi 1968; Pandya \& Sukh-Dev 1990; Chinnappa et al. 2015). These genera both encompass five species each (Appendix 1). The taxonomic relationship of Pagiophyllum and Brachyphyllum is a unclear at the family level (see Chinnappa \& Rajanikanth 2017). These taxa are herein provisionally placed under the Araucariceae after Bose \& Maheshwari (1975). Pollen belonging to the Araucariaceae is known as Araucariacites Cookson and Callialasporites SukhDev (Appendix 2).
The other significant conifers found in the flora are taxa belonging to Elatocladus where the genus is represented by six species (Appendix 1). Among them E. plana (Feistmantel) Seward is common and widely distributed. The specimens of the genus from Vemavaram show comparatively large sized leaves compared to material from the Raghavapuram and Gangapur. In the Krishna-Godavari flora, the genus is represented only as impressions of vegetative leafy twig, the cuticles and reproductive structures have so far not been recovered. Therefore the precise taxonomic affinity of the genus is unclear. Since the genus Elatocladus from India has already been related to Podocarpaceae (Chinnappa \& Rajanikanth 2017), it is treated here under the same family i.e., Podocarpaceae. Pollen allied to the Podocarpaceae is known under four genera: Microcachrydites Cookson, emend. Couper, Platysaccus Naumova, emend. Potonié, Podocarpidites Cookson, emend. Couper, and Podosporites Rao and constitute a great deal of the microflora, both qualitatively as well as quantitatively. Among them, Podocarpidites shows the highest species diversity with eight species (Appendix 2). The quantitative representation of the genus is also very high and alone represents more than $20 \%$ in the pollen spectra (Venkatachala $\&$ Sinha 1986). Less abundant are the genera Podosporites represented by three species respectively. Microcachrydites and Platysaccus are represented by a single species each (Appendix 2).

The Taxales are comparatively rare with only a single genus and species of macro-remains Torreyites constricta Sahni being known only from the Vemavaram Formation (Sahni 1931). A very few plant fossil records can be assigned to this genus with confidence (Sahni 1931). The vegetative shoots bearing spirally arranged and distichously placed linear leaves characterized by two well marked stomatal grooves on the lower surface and absence of distinct midrib resembling in habit those of Torreya were usually assigned under Torreyites (Seward 1919). However, because the bands represent grooves to which the stomata were confined referral to Torreyites is not always possible when cuticles are not preserved (Seward 1919; Sahni 1931). The only reliable character is absence of a distinct midrib and the characteristic leaf shape. Although the fossil leaves were identified based on the characters of the extant genus, without reproductive organs it is impossible to determine the precise systematic position of shoots of this common form and these generic names do not imply any direct relationship with the extant members (Seward 1919). The records of taxalean woods (Taxaceoxylon) in India during Mesozoic times (Rajanikanth \& Sukh-Dev 1989) however, suggest their possible existence as suggested by Sahni (1928).

Genera like Harrisiophyllum Pant, Srivastava \& Pant and Pityospermum Nathorst are known from a single isolated specimen each (Chinnappa et al. 2015). Although cuticles of the Harrisiophyllum were described from Bansa, South Rewa Formation by Pant et al. (1983), they did not provide enough information to narrow down the taxonomic affinity of the genus to the family level. Records of Pityospermum, a winged seed, are not common from the Early Cretaceous sediments of India. Pityospermum sp., from the Sriperum- 
budur Formation, Palar Basin located in Tamil Nadu, India (Jeyasingh \& Kumarasamy 1994) and P. godavarianum from the Raghavapuram Formation (Chinnappa et al. 2015) were the only reports known to date. The precise taxonomic affinity of the seeds of this type is not clear. The striking resemblance between such seeds and seeds of recent Pinus and other Abietineaceae (Seward 1919) suggest their possible affinities with Pinaceae or/and Abietineaceae. However, until more evidence is found it is not possible to confirm their family affinity. Therefore, here we consider them under the broad group Coniferales. Recovery of Abietineaepollenites pollen belonging to Abietineaceae from the Krishna-Godavari Basin (Ramanujam 1957) is noteworthy.

Classopollis Pflud emend. Pocock \& Jansonius are abundant in the Early Cretaceous successions of India (e.g. Ramanujam \& Rajeshwara Rao 1979; Venkatachala \& Sinha 1986) and other Gondwanan and non Gondwanan land masses (Vakhrameev 1991). They are represented here by three species (Appendix 1). In spite of rich records of Classopollis from the Early Cretaceous sediments of India, nothing is known about their parent plants. The type of pollen is generally presumed to be produced by Cheirolepidiaceae (Venkatachala 1966). However, such pollen is shown to be produced by wide variety of fossil-taxa including Pagiophyllum and Brachyphyllum type fossils (Kendall 1949; Couper 1955; Venkatachala 1966; Srivastava 1976; Tosolini et al. 2013). Such leaf types belong to the Cheirolepidiaceae (Tosolini et al. 2013), the Podocarpaceae and Araucariaceae (Harris 1979). In India, Classopollis pollen has mostly been recovered from the same sediments yielding the species of Pagiophyllum and Brachyphyllum (Ramanujam \& Rajeshwara Rao 1979). However, it has never been recovered from in situ cones attached with Pagiophyllum and/or Brachyphyllum. The taxonomic affinities of this foliage in India (see Chinnappa \& Rajanikanth 2017), and the parent taxa of Classopollis necessitates awaiting further evidence.

Conifer remains in the Early Cretaceous Krishna-Godavari flora include two species of detached strobili placed under Conites (Appendix 2). Although there can be little doubt that it is a conifer reproductive organ not much is known about their structure and their precise affinity. A number of pollen forms of unknown conifer affinity also occur in the KrishnaGodavari basin. They are listed in the Appendix 2.

\section{ANGIOSPERMS}

Angiosperm macrofossil remains from the Early Cretaceous sequences of India are rare (Chinnappa \& Rajanikanth 2017). Microfossil reports from subsurface and surface data from the Early Cretaceous sequences of India clearly indicate their occurrence by this time (Mehrotra et al. 2012). The Early Cretaceous microfossil assemblage from Krishna-Godavari Basin includes about thirteen species of angiosperm pollen (Appendix 2). A small assemblage of megafossils resembling flowering plants were recovered from the Early Cretaceous sequences Krishna-Godavari Basin (Chinnappa 2016). These fossil taxa mostly resemble an aquatic plants with ribbon shaped and dissected leaves.

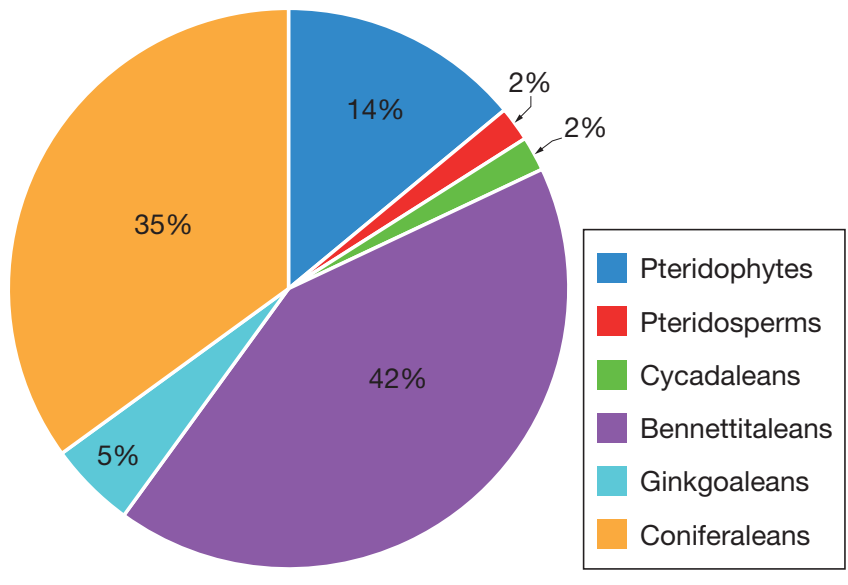

FIG. 7. - The macrofloral diversity of the various plant groups in the KrishnaGodaveri Basin (East Coast of India).

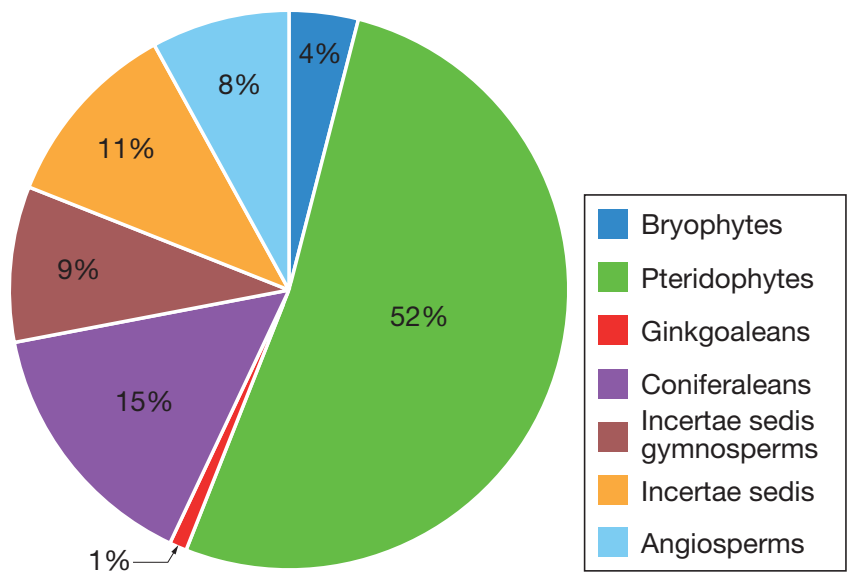

FIG. 8. - The microfloral diversity of the various plant groups in the KrishnaGodaveri Basin (East Coast of India).

\section{FLORAL DIVERSITY}

MEGAFLORA

Taxonomic analysis of the megaflora, which includes leaves and cone scales (Figs 4; 5) demonstrate the presence of pteridophytes, and gymnosperms. A total of 81 species under 20 genera have been reported to date. The pteridophytes constitute 11 species under six genera representing $14 \%$ in the flora. The gymnosperms are a major element in the flora, they include pteridosperms, bennettitaleans, cycadaleans, ginkgoleans and conifers. With two species and two genera the pteridosperms comprise $2 \%$. The bennettitaleans are dominant elements of the flora and they include 34 species under six genera with $42 \%$ of the species share. The conifers constitute 28 species under 8 genera and they represent $35 \%$ of the total diversity. The ginkgoleans and cycadaleans are minor components in the flora in terms of diversity. The former include four species under a single genus and make up $5 \%$, and the latter consists of two species and one genus with $2 \%$. Although, the species diversity of the ginkgoleans is less, they are extremely abundant in the Raghavapuram Formation. The percentage share of each group has shown in the Figure 7. 


\section{MiCROFLORA}

The Early Cretaceous microfloras (spore/pollen) from the KrishnaGodavari Basin are rich and diverse (Ramanujam 1957; Kar \& Sah 1970; Venkatachala \& Sinha 1986; Prasad \& Pundir 1999; Mehrotra et al. 2010, 2012; and present study). These studies reported a range of taxa affiliated to the bryophytes, pteridophytes, gymnosperms and angiosperms (Appendix 2). Although, the conifer pollen dominates the assemblage, pteridophytes spores are also very abundant. The conifers include 23 species under seven genera and it comprises $15 \%$ in the flora. Other gymnospermous taxa include ginkgoaleans and taxa of uncertain affinity (incertae sedis). The ginkgoaleans consists of two species under a single genus and make up a small percentage (1\%) in the flora. The taxa placed in incertae sedis include 14 species in nine genera and represents $9 \%$. The pteridophytes, composed of 82 species, are grouped under 39 genera and occupy $52 \%$ of species diversity. The presence of diverse and abundant spores suggests the luxurious growth of the group (Appendix 2). The percentage share of each group is shown in the Figure 8.

The significant contributions of the microflora are the reports of bryophytic spores and angiosperm pollen (Mehrotra et al. 2010, 2012). Presence of bryophytic spores suggests existence of the group in the Krishna-Godavari flora, although the megafloral elements have not yet been reported. The bryophyte spores are comparatively rare and they include only seven species in six genera and comprise $4 \%$ of species diversity. The records of the angiospermous pollen are of special interest here. They are here represented by 13 species under 10 genera, which occupy $8 \%$ of species diversity in the total flora. There are a few more taxa of uncertain affinity, which are here referred to incertae sedis, they include 18 species in 13 genera and constitute $11 \%$ of species diversity.

\section{TAPHONOMIC IMPLICATIONS}

The concentration and degree of fragmentation of the plant fossils has been often used as indicative of original vegitational relationship (auto-allochthonous). Plant taphonomic studies by Ferguson (1985), Spicer \& Greer (1986), Gastaldo (1988), Spicer (1991) and others suggested that the degree of fragmentation can be related to the distance travelled by a given plant material before its fossilization. This fragmentation determines that leaves in general cannot be transported long distances before their burial and fossilization (Spicer 1991). Additionally, the fragmentation of the plant parts in the fossil floras is also due to other physical and biological factors (Ferguson 1985). Generally, the fossils also get badly mutilated during the process of recovery from sediments like highly cracked and jointed mudstone (Baksi 1968).

The fragmentary nature of the recovered specimens here indicates that the plant fossils were subjected to transportation (Behrensmeyer \& Hook 1992). The degree of fragmentation among the various plant assemblages is not uniform, thus suggesting distances travelled by these plant fossils differ. Ferns were mostly recovered as isolated fragmentary pinnules and their concentration is poor. The paucity and fragmentation of the fern leaves can be explained by their delicate structure and poor preservation potential (Gastaldo 1988, 1992; Spicer 1991). However, spores of this group are diverse and abundant suggesting these plants were probably not from the far distance and their source might be close to the depositional site (Venkatachala \& Sinha 1986; Spicer 1991). The leaves of Taeniopteris are rare and are recovered as isolated fragments (Pandya \& Sukh-Dev 1990; Prasad \& Pundir 1999; Chinnappa et al. 2015) suggesting that perhaps they were produced by plants that did not grow in the immediate vicinity of the depositional environment. The bennettitaleans are common and well preserved in many cases the leaves preserved most of its length (Fig. 4B). These compound leafy rachises with intact pinnae are suggesting their rapid burial and minimal transportation (Ferguson 1985). Therefore, the parent plant that produced these leaves is here considered as a local and was probably growing within or very near the depositional environment. Ginkgo leaves are common in the Krishna-Godavari flora and are locally more abundant in the Raghavapuram Formation. These leaf types are well preserved with petioles, however, in a few cases both the base and apex of the leaf are missing (Fig. 4I). This suggests leaves might be exposed to short distance transportation. The pollen of this group is also well preserved. It is rational to consider them as local constituents of the flora based on the preservational attributes.

The conifers in the flora include araucarians, podocarps and members of the Taxaceae. The araucarians constitute moderately preserved leafy axes with branching preserved (Fig. 5B, E), and cone scales with clear seed marks (Fig. 4K). The preservation mode of these taxa suggests considerable transportation before their fossilization, consequently they are considered here as regional elements. The podocarps occur sporadically in the flora; they are mostly represented by isolated fragmentary leaf axes and a winged seed (Figs 4L; 5D, G). They possibly travelled into the depositional site from regional uplands. High frequency of saccate pollen produced by Podocarpaceae is also indicative of its upland habitat (Venkatachala \& Sinha 1986; Abbink et al. 2004). The saccate pollen must have been flew from the uplands and entered into the depositional sites.

The megafloral records of bryophytes are not known. The presence of the spores such as Foraminisporis, Coptospora, Cooksonites and Stereisporites indicates that the bryophytes also constitute as part of the flora (Mehrotra et al. 2012). The absence of macrofossil remains is probably because of their poor preservation capacity and taphonomic constraints (Reader \& Stewart 1972; Spicer 1991). The bryophytes in general include small herbs with delicate foliages that make them difficult to preserve in fossil record.

The early angiosperms are mostly thought to be herbs and/ or small shrubs (Taylor \& Hickey 1996; Sun et al. 2002; Field et al. 2004, 2009). The herbaceous nature might be a possible reason for the dearth of their macrofossils (Spicer 1991), yet their pollen can be preserved. Angiosperms are rare in the Indian Early Cretaceous flora and represented by a few poorly preserved leaves which are ribbon shaped and dissected (Chinnappa 2016). The characteristic shape of these leaves suggest their aquatic nature. 

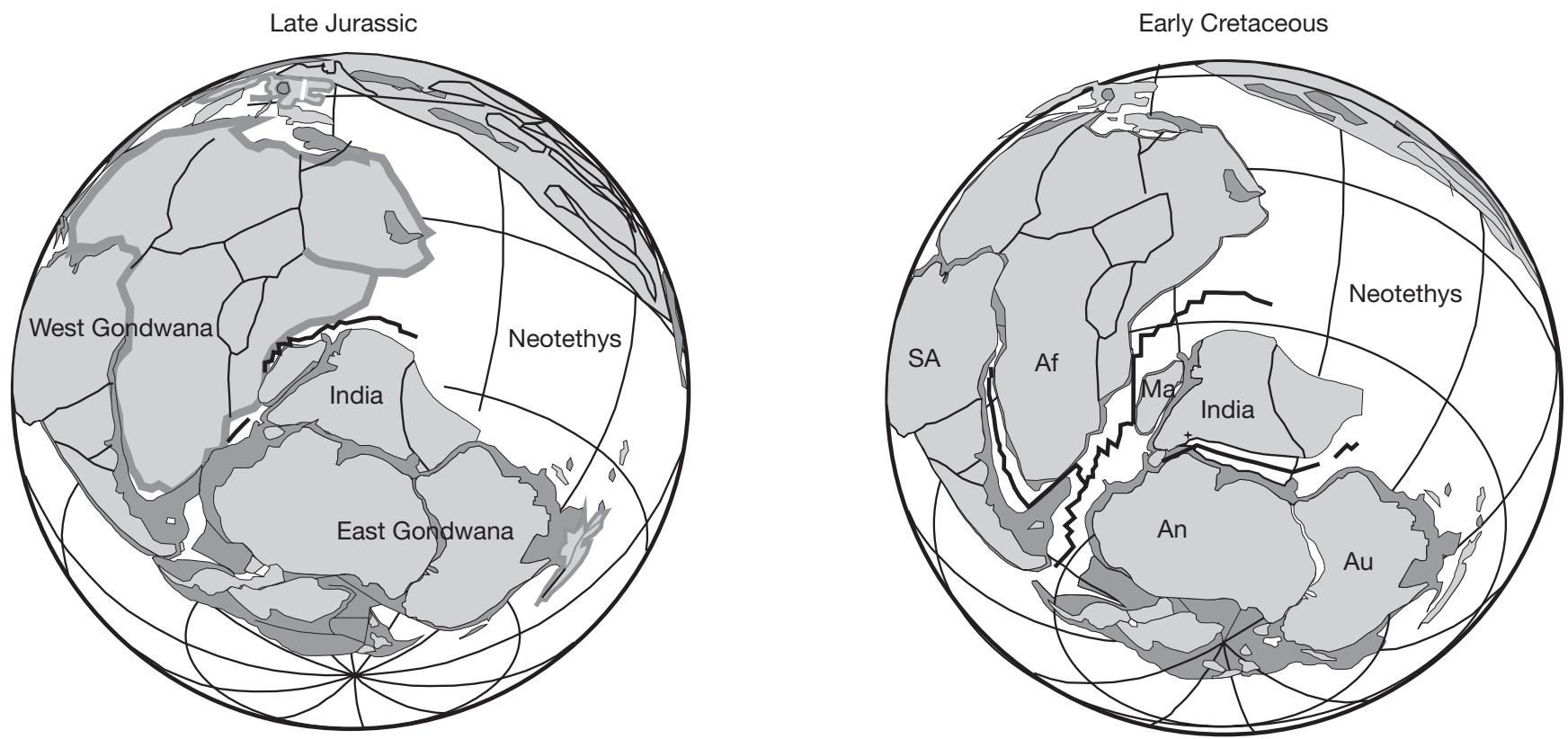

FIG. 9. - Global Palaeogeography map during the Jurassic and Cretaceous periods (after Chatterjee et al. 2013).

The above account suggests that many of the plant fossils were most likely exposed to some pre-depositional sorting and abrasion suggesting that perhaps they were produced by plants that did not grow in the immediate vicinity of the deposition environment. This could be the probable reason for the low diversity and low number of specimens in the samples and particularly explain the lack of delicate remnants such as sporangia and frond fragments of bryophytes in the megafossil flora. Nonetheless, the study also indicates the flora is taxonomically less diversified as it is (Chinnappa 2016). Experimental observation of leaf transportation in fluvial systems by Spicer \& Greer (1986) indicated that the maximum distance travelled in ideal conditions is less than $1.5 \mathrm{~km}$. Thus, the floral components were probably drifted from local to regional sites. Therefore, the present assemblage is considered to represent parauto- to allo-chthonous elements and the flora mostly includes the local to regional vegetation. It has also been demonstrated that a low energy condition within a fluvial system was inferred on the basis of grain size parameters (Rao 2001). Fluvial settings generally reflect the local flora though the herbaceous component is rare (Burnham 1989).

\section{PALAEOECOLOGICAL IMPLICATIONS}

Extant bryophytes mostly grow in moist and shady areas, as they require water to complete their life cycle. Only a few species are known to withstand water stress but even these taxa require water during the reproductive stage (Abbink et al. 2004; Schrank 2010). Therefore, this group is here considered to grow at river banks and back-swampy settings as indicated by their association with silt and mud (Boggs 2006). The swampy environments is also supported by an unequal distribution of phytoplanktons (Venkatachala \& Sinha 1986)
Ferns have mostly been considered to grow "under moist, rather warm conditions either in marshes, along riverbanks or as understorey in forests" (Van Konijnenburg-Van Cittert 2002). Only a few taxa (e.g. Gleichenia [Gleicheniaceae], Phlebopteris and Weichselia [Matoniaceae]) can tolerate full sunlight and are able to adapt to the stress related conditions (Van Konijnenburg-Van Cittert 2002; Abbink et al. 2004; Schrank 2010). However, the majority of the Jurassic-Cretaceous ferns are considered to be elements of moist lush vegetation (Harris 1961) often occurring near river banks (Pelzer et al. 1992). The group is generally believed to attain high abundances under relatively humid conditions optimal for plant growth. This is highlighted by relations between lithologies indicative of moist environments with high spore abundances (Maheshwari \& Jana 2004). The ferns in the Krishna-Godavari lithologically associated with claystone/mudstone and silty sandy stone. This facies association indicates overbank and backswampy depositional settings (Boggs 2006)

The pteridosperms such as Pachypteris indica (Oldham \& Morris) Bose \& Roy and Thinnfeldia vemavaramensis (Feistmantel) Chinnappa, Rajanikanth \& Rao are associated with the sandstone and shale/mudstone facies respectively. The former is also known from the other basins like Kutch, Satpura, Rajmahal and Mahanadi (Rajanikanth \& Chinnappa 2016), while the later is exclusive to the Krishna-Godavari Basin. Pachypteris indica is considered to produce large sized bushes that formed mangrove thickets along the river mouth inundated by tides (Banerji 2004). The frequent association of Thinnfeldia vemavaramensis with marine fossil fauna and leathery leaves suggest its coastal habitat.

Mesozoic cycadaleans are considered to occupy the low-lands and share the forest floor with ferns and favour fairly boggy conditions (Abbink et al. 2004). Taeniopteris spatulata McClelland is the only possible cycadalean taxa reported from the Krishna- 
Godavari Basin. This taxon is considered to be grown on the river floodplain, distal to the river channel, but occupied fairly boggy conditions in clearings or near the forest margins (Chinnappa \& Rajanikanth 2017). Where light was reduced from a closed canopy of conifers, cycadaleans colonized the forest floor in patches and together with fern thickets and presumably preferred areas of the canopy with less dense stands of trees.

The members of bennettitaleans were considered to grow in diverse niches, ranging from delta areas to coastal margins or in upland areas (Vakhrameev 1991; Abbink et al. 2004). However, it is generally assumed that most species favored humid environment (Pott et al. 2008) and preferred to grow at coastal margins (Vakhrameev 1991) and lowlands (Krassilov 1975). The spatial heterogeneity in the distribution pattern of various taxa in the fossil assemblages of the studied flora and their association with different sedimentary facies support the above views. The taxa like Otozamites acutifolius Feistmantel, O. exhislopi Bose, O. imbricatus Feistmantel, O. gondwanensis Bose, D. hallei Sahni \& Rao, D. ommevaramensis Chinnappa, Rajanikanth \& Rao, Pterophyllum footeanum Feistmantel, P. incisum Sahni \& Rao and Ptilophyllum heterophylla Chinnappa, Rajanikanth \& Rao are rich and exclusive to the near sea deposits and frequent association of the leaves with marine fauna suggests coastal habitat. Presence of recurved leaf margin, strongly cutinized guard cells and sunken stomata as observed in the species of Otozamites (Bose 1974; Bose \& Banerji 1984) and characteristic leathery nature of the leaves is considered to be a strategy to minimize the water loss in the coastal zone (Vakhrameev 1991; Villar de Seoane 2001; Wright et al. 2005). The association of these leaves with shale is also in congruence with above interpretations (Boggs 2006). Similarly, the association of the other bennettitaleans such as Dictyozamites indicus Feistmantel, Pterophyllum kingianum Feistmantel, Ptilophyllum deodikarii Mahabale \& Satyanarayana, P. tenerrimum (Feistmantel) Bose \& Kasat, Ptilophyllum cf. institacallum Bose, Ptilophyllum cf. amarjolense Bose, Ptilophyllum cf. gladiatum Bose \& Sukh-Dev, Ptilophyllum cf. horridum Roy and Ptilophyllum cf. jabalpurense Jacob \& Jacob with cycadaleans and ferns indicates that, they are dwelling in the lowland areas. Their sedimentary association with claystone and clay sandstone also suggests flood deposits (Boggs 2006). The taxa like Dictyozamites feistmantelii Bose \& Bano, Ptilophyllum acutifolium (Morris) Bose \& Kasat, P. cutchense (Morris) Bose \& Kasat have wide distribution and they are common in all type of lithologies and found in every fossil assemblage. This suggests that these taxa might favor the wide ecological niches.

Species of Ginkgo occur frequently in the flora; they represent mostly deciduous moist loving plants, growing alongside conifers. Although, the extant species is restricted to China, the ginkgoleans had wide distribution during the Mesozoic (Royer et al. 2003). Mesozoic ginkgoaleans seem to have been able to tolerate a wide range of climates from warm and wet temperate (or even cool) in coastal plain and lowland to inland riparian/swamp environments, respectively. In spite of their broad adaptability, however, it appears that the ginkgoaleans on the whole were more abundant and diverse in mesic, warm temperate to temperate climates and inhabited stable and ecologically saturated environments such as wetlands (Royer et al. 2003; Zhou 2009). The low diversity of the genus in the modern flora also suggests this ecologically restricted distribution (Alvin \& Watson 1996). The Ginkgo leaves reported from the Krishna-Godavari Basin are associated with mudstone facies, which is indicative of floodplain deposits (Boggs 2006).

The coniferous taxa such as Brachyphyllum regularis Borkar \& Chiplonkar, B. sehoraensis Bose \& Maheshwari, Pagiophyllum gollapallensis Pandya \& Sukh-Dev, and Pagiophyllum cf. grantii Bose \& Banerji are found in an assemblage consists of ferns and cycadophytes, suggesting they share similar habitats such as lowlands. The presence of thin cuticle and amphistomatic condition in Brachyphyllum sehoraensis and Pagiophyllum cf. grantii (Bose \& Maheshwari 1973; Bose \& Banerji 1984; also indicate their growth at high water availability. Yet some species of Brachyphyllum such B. feistmantelii (Halle) Sahni, B. rhombicum Feistmantel, Pagiophyllum cf. marwarensis Bose \& Sukh-Dev and P. ommevaramensis Chinnappa, Rajanikanth \& Rao preferred to grow at coastal regions as indicated by their lithofacies association with shale and frequent mixing with marine fauna. The fertile parts reported here probably produced by Brachyphyllum and/or Pagiophyllum. Extant members of araucarians frequently grow near shores as they can withstand the influence of salt wind (Vakhrameev 1991). Their leathery leaves and thick cuticles are adaptations to such type harsh conditions. Evidence from the megafossil record indicates that araucarian trees usually grow in lowlands, probably coastal margins and preferred cooler environments (Venkatachala 1966; Ramanujam 1980; Vakhrameev 1991).

The members of podocarpaceae are numerically less represented in the megaflora when compared to any other members, but they are abundant in the microflora. In spite of their robust nature, the week representation of podocarps in the flora, in terms of their abundance suggest they probable growing away from the depositional site and find difficult to incorporate in the fossil assemblages (Spicer 1991). Being able to fly with wind the pollen might had reached the depositional site and preserved in good number. Today podocarps are particularly common in mountain areas of the tropics and subtropics. During the Mesozoic, the family inhabited relatively dry areas of upland forest (Vakhrameev 1991) or cool, wet upland forest (Doyle et al. 1982). High frequency of saccate pollen produced by Podocarpaceae is also indicative of its upland habitat (Abbink et al. 2004). The association of taxaceans with podocarps is indicative of their similar distribution.

The palaeoeocology of the angiosperms in the present flora is not clear due to the limited megafossils evidance and lack of knowledge regarding their systematic affinities. The characteristic shapes of these leaves (ribbon shaped and dissected) suggest their aquatic nature (Chinnappa 2016). It has been believed that the early angiosperms were herbs/shrubs and mostly preferred to grow near water bodies (Feild et al. 2009). The angiosperms pollen reported here, possibly originated from the plants of the similar habitat.

From the above discussion that the spore-producing bryophytes/pteridophytes are generally believed to prefer river banks and still some may have been underground cover under ben- 


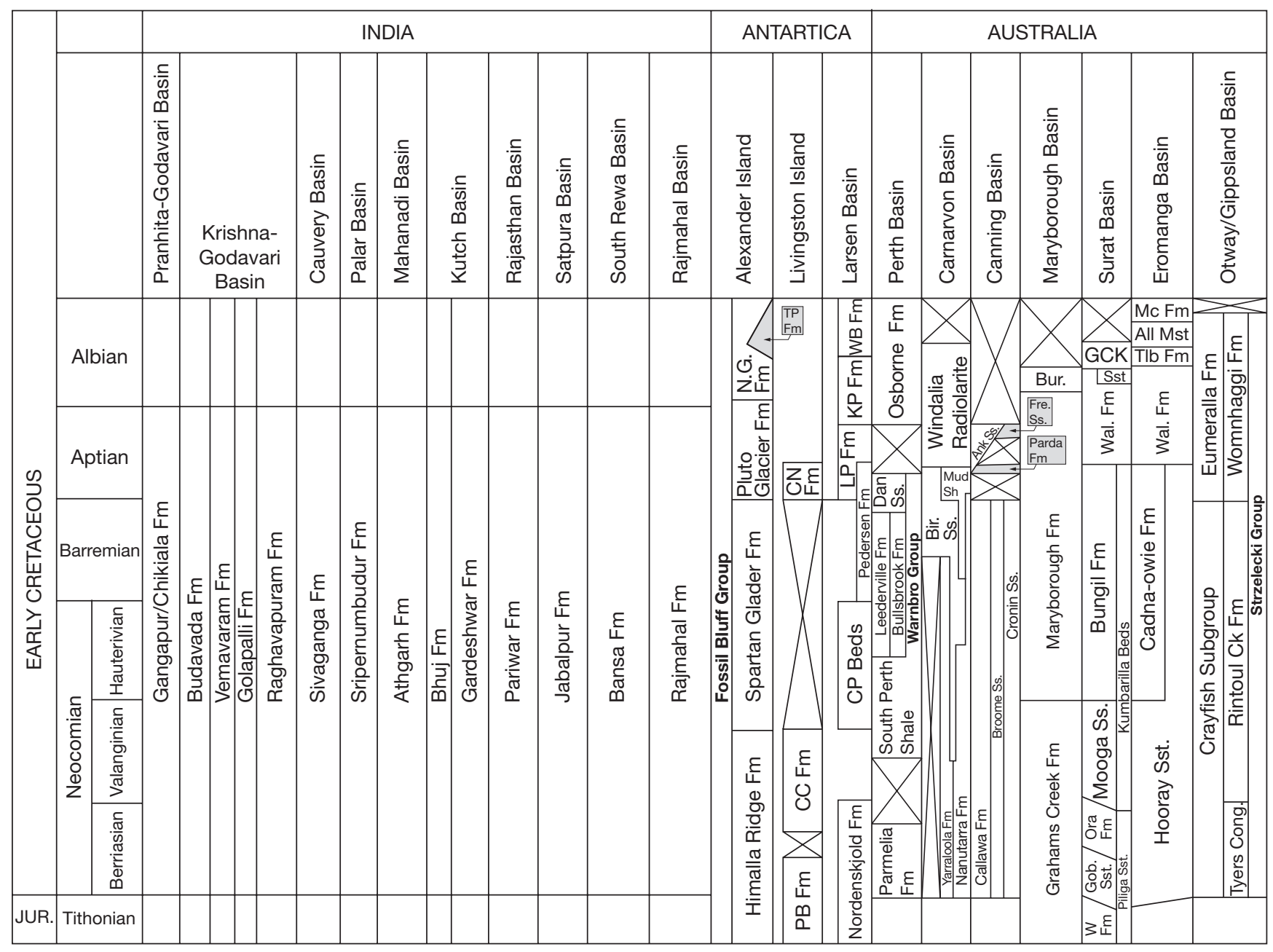

FIG. 10. - Correlation chart of the different Early Cretaceous basins from India, Antarctica and Australia, deducted from the information available in this article. Abbreviations: All Mst, Allaru Mudstone; Ank Ss, Anketell Sandstone; Bir Ss, Birdrong Sandstone; Bur, Burrum Coal Measures; CC Fm, Chester Cone Formation; CN Fm, Cerro Negro Formation; Cong, Conglomerate; CP Beds, Crabeater Point Beds; Dan Ss, Dandaragan Sandstone; Fre Ss, Frezier Sandstone; GCK, Griman Ck Formation; Gob. Sst, Gobb Sandstone; KP Fm, Kotick Point Formation; LP Fm, Lagrelius Point Formation; Mc Fm, Mackunda Formation; Mud Sh, Muderong Shale; N.G. Fm, Neptune Glacier Formation; Ora Fm, Orallo Formation; PB Fm, President Beaches Formation; Sst, Surat Siltstone; TIb Fm, Toolebuc Formation; TP Fm, Triton Point Formation; Wal. Fm, Wallumbilla Formation; WB Fm, Whisky Bay Formation; W Fm, West Formation.

nettitaleans and conifers. The cycadaleans probably grew on the river floodplain, distal to the river channel, but preferred fairly boggy conditions in clearings or on the outskirts of the forest. The bennettitaleans are considered to have inhabited lowlands to coastal regions. The ginkgoaleans are wetland lovers. The members of araucarian conifers are interpreted to dwell in lowlands yet some species may extend into coastal margins. The podocarps and taxaceans possibly occupied the upland regions. Palaeoecological reconstruction of the Early Cretaceous Krishna-Godavari Basin flora is illustrated in Figure 6.

\section{PHYTOGEOGRAPHICAL CORRELATION}

To a large extent type and distribution pattern of the land plants is constrained by its immediate physical environment (Spicer et al. 1994). This constraint has operated thorough out land plant evolution and has repeated morphologies under similar environmental conditions. During the Early Cretaceous, Indian subcontinent along with Australia and Antarctica constitute an east Gondwana (Fig. 9). The palaeoclimatic maps of the Scotese (2000) have shown that these land masses were under the influence of warm temperate conditions. Therefore, it is expected to be floral similarities among the Indian subcontinent, Australia and Antarctica. The palaeogeographic maps of the Jurassic and Cretaceous periods have shown that the east coast of India is closely associated with Western Australia and east Antarctica. Hence the comparison is here restricted to the floras of these regions.

The poor dating of the Indian Mesozoic sediments is one of the significant constraints to compare the Indian Early Cretaceous flora with the other Gondwana floras. Unlike the Early Cretaceous successions of Australia and Antarctica, there are no precise age determinations for the Early Cretaceous successions of India (Fig. 10). The Indian Early Cretaceous successions were assigned age ranging from Neocomian to 
Aptian almost covering the entire Early Cretaceous period. Palaeobotanical studies around the globe, however, indicated that except the appearance of angiosperms there are not many changes in compositions of flora during the intervals of the Early Cretaceous. This permits a broad scale comparison of the Indian Early Cretaceous flora with that of Australia and Antarctica.

The President Head flora, Antarctica, is distinctive, and appears to be characteristic of a high latitude flora (Cantrill 2000). Bryophytes and hepatophytes are abundant and diverse, a feature unique to the Cretaceous Antarctica (Drinnan \& Chambers 1986; Cantrill 1997a, b). The President Head flora shares two species, Dictyozamites falcatus Medlicott \& Banford and Pachypteris indica (Oldham \& Morris) Bose \& Roy and also eleven genera: Lophosoria Presl (= Gleichenia/Gleichenites Goeppert), Sphenopteris, Pachypteris, Taeniopteris, Ptilophyllum, Dictyozamites, Cycadolepis, Araucarites, Pagiophyllum, Conites and Elatocladus. However, at species level they differ from the Indian taxa. The most similar generic and possibly even specific comparison appears to be with the flora of the Western Australia. Similar to the Early Cretaceous KG flora, the Neocomian Western Australian flora is also dominated by bennettitaleans (McLoughlin 1996). Both these floras share several genera (Gleichenites [= Microphyllapteris], Cladophlebis, Sphenopteris, Thinnfeldia, Taeniopteris, Ptilophyllum, Araucarites [araucarian cone scale], Pityospermum [winged seed], Elatocladus) and some species like Ptilophyllum acutifolium and $P$. cutchense in common. The principle difference between the two floras is in the presence or absence of Dictyozamites. While it is absent from the Western Australian flora, it is more common in the Krishna-Godavari flora.

The phytogeographical distribution and diversity of the Indian East Coast flora during the Early Cretaceous was influenced by drifting of the Indian subcontinent. During this period initiation and separation of East Coast from the East Antarctica and West Australia basins influenced deposition of plant relics (Sastri et al. 1981; Lal et al. 2009). The similar floral constituents from these regions support such an interpretation (Dettmann 1963; Dettmann \& Playford 1969; Truswell et al. 1999; Sajjadi \& Playford 2002a, b; Chinnappa 2016). Conversely, the Indian East Coast Early Cretaceous flora differs slightly from that of the Antarctica (Bose et al. 1991; Cantrill 2000) and Australia (Hill 1994; McLoughlin 1996; McLoughlin et al. 2002) floras in the prevalence of bennettitalean remains, although the general composition of conifers is similar.

The Early Cretaceous floras from India are also well known from the other basins such as Cauvery, Palar, Mahanadi, Pranhta-Godavari, Rajmahal, Kutch, Rajasthan Satpura and South Rewa (Fig. 1). The Krishna-Godavari Basin represent diverse plant groups, they are primarily dominated by the bennettitaleans. Thus the floras show close similarity with the floras from other pericratonic Early Cretaceous succession such as Cauvery, Palar and Mahanadi. The taxa common to these basins includes Taeniopteris spatulata McClelland, Ptilophyllum acutifolium, P. cutchense (Morris) Bose \& Kasat, Elatocladus plana (Feistmantel) Seward and Araucarites cutchense Feistmantel. The fossil flora from adjoining intracratonic rift basins i.e., Pranhta-Godavari (PG) differs in the dominance of conifers. Except Ptilophyllum other bennettitalean genera like Dictyozamites, Otozamites, Anomozamites, and Pterophyllum are rare and Ginkgo is totally absent from the PG flora. Among the other Early Cretaceous floras of India, the KG flora is closely comparable with the flora of Rajmahal (Banerji 2000). Both these floras are predominated by bennettitalean foliages and share many taxa. The taxa common to both the floras are: Dictyozamites falcatus, D. indicus Feistmantel, Otozamites imbricatus, Ptilophyllum distans (Feistmantel) Bose \& Kasat, P. incisum, Ptilophyllum acutifolium, $P$. cutchense, $P$. rarinervis (Feistmantel) Bose \& Kasat, P. tenerrimum, Williamsonia blandfordii Feistmantel, W. indica Seward, W. kakadbhitensis Pandya \& Sukh-Dev and Cycadolepis indica Gupta, Brachyphyllum expansum (Sternberg) Seward, Pagiophyllum cf. marwarensis Bose \& Sukh-Dev, Elatocladus confertus Seward \& Sahni, E. plana, E. jabalpurensis (Feistmantel) Sahni and E. tenerrimus (Feistmantel) Sahni. The major difference between these floras is in presence and/or absence of pentoxylaleans, which are common from the Rajmahal.

\section{Acknowledgements}

The author Rajanikanth is thankful to the Prof. Sunil Bajpai, Director, Birbal Sahni Institute of Palaeosciences, Lucknow and Chinnappa is thankful to management of Andhra Loyola College, Vijayawada for their encouragement and support and Dr Van Konijnenburg-Van Cittert, J. H. A (emeritus professor at the University of Leiden) and Dr Spicer, R. A., for their suggestions and for attention to the language of an initial draft of the paper. We thank Dr Maria Barbacka and an anonymous reviewer for their valuable, constructive comments and suggestions on the manuscript.

\section{REFERENCES}

Abbink O. A., Van Konijnenburg-Van Cittert J. H. A. \& VissCHER H. 2004. - A sporomorph ecogroup model for the Northwest European Jurassic-Lower Cretaceous: concepts and framework. Netherlands Journal of Geosciences/Geologie en Mijnbouw 83: 17-38. https://doi.org/10.1017/S0016774600020436

Alvin K. L. \& Watson J. J. 1996. — An English Wealden floral list, with comments on possible environmental indicators. Cretaceous Research 17: 5-26. https://doi.org/10.1006/cres.1996.0002

BAKSI S. K. 1964. — Fossiliferous Gollapalli Sandstone from a new locality and its significance. Quarterly Journal of the Geological, Mining and Metallurgical Society of India 36 (4): 171, 172.

BAKSI S. K. 1967. - On new occurrence of Gingoites feistmantelii Bose \& Sukh Dev (1958) from the coastal Gondwana of South India. Current Science 36: 580.

BAKSI S. K. 1968. — Fossil plants from Raghavapuram Mudstone, west Godavari District, Andhra Pradesh. Palaeobotanist 16: 206-215.

BAKSI S. K. 1977. - Marine transgression, sedimentation and tectonics of the West Godavari coastal rocks of Andhra Pradesh. Indian Journal of Earth Sciences, S. Ray Volume: 67-94.

BANERJI J. 2000. - Megafloral diversity of the upper Gondwana sequence of the Rajmahal Basin, India. Journal of African Earth Sciences 31: 133-144. https://doi.org/10.1016/S08995362(00)00078-6 
BANERJI J. 2004. - Mesozoic megaflora of Kachchh Basin and its palaeoecological interpretation, in SRIVASTAVA P. C. (ed.), Vistas in Palaeobotany and Plant Morphology: Evolutionary and Environmental Perspectives. Prof Pant, D. D. memorial volume. U.P. offset, Lucknow, India: 199-206.

BARBACKA M. \& BodOR E. 2008. - Systematic and palaeoenvironmental investigations of fossil ferns Cladophlebis and Todites from the Liassic of Hungary. Acta Palaeobotanica 48 (2): 133-149.

Behrensmeyer A. K. \& HOOK R. W. 1992. - Paleoenvironmental contexts and taphonomic modes in the terrestrial fossil record, in Behrensmeyer A. K., Damuth J., Dimichele W. A., Potts R. H., Sues D. \& Wing S. L. (eds), Terrestrial Ecosystems through Time. The University of Chicago Press, Chicago: 15-138

BISWAS S. K. 1992. - Tectonic framework and evolution of graben basins of India. Indian Journal of Petroleum Geology 1: 276-292.

BlandFord W. T., BlandFord H. F. \& TheObalad W. 1856. On the geological structure and relations of the Talchir coal field in the district Cuttack. Memoirs of Geological Survey of India 1: 33-38. https://biodiversitylibrary.org/page/33105917

Boggs JR S. 2006. - Sedimentology and Stratigraphy. Pearson Education, Upper Saddle River, 662 p.

Bose M. N. 1974. - The genus Otozamites Braun from the Mesozoic rocks of India. Palaeontographica Abteilung B 29: 100-106.

Bose M. N. \& BANerJi J. 1984. - Fossil floras of Kachchh. I. Mesozoic megafossils. Palaeobotanist 33: 1-189.

Bose M. N. \& MAHEShWARI H. K. 1973. - Brachyphyllum sehoraensis, a new conifer from Sehora, Narsinghpur District, Madhya Pradesh. Geophytology 3: 12-15.

Bose M. N. \& MAHESHWARI H. K. 1975. - Mesozoic conifers, in Surange K. R., Lakhanpal R. N. \& Bharadwaj D. C. (eds), Aspects and Appraisals of Indian Palaeobotany: 212-233.

BosE M. N. \& JAIN K. P. 1967. — Otozamites vemavaramensi sp. nov. from the Upper Gondwana of the East Coast of India. Palaeobotanist 15: 314, 315.

Bose M. N., TAYlor E. L. \& TAYlor T. N. 1991. - Gondwana floras of India and Antarctica- a survey and appraisal, in TAYLOR E. L. \& TAYLOR T. N. (eds), Antarctic Palaeobiology. Springer, New York: 118-148.

BURNHAM R. J. 1989. — Relationships between standing vegetation and leaf litter in a paratropical forest: implications for paleobotany. Review of Palaeobotany and Palynology 58: 5-32. https://doi.org/10.1016/0034-6667(89)90054-7

CANTRILl D. J. 1997a. - Floristics of a Lower Cretaceous freshwater lake deposit from president head, Snow Island, South Shetland Islands, in RicCI C. A. (ed.), The Antarctica Region: Geological Evolution and Processes. Proceedings of the VII International Symposium of Antarctica Earth Science, Siena, Italy 1995. Terra Antarctica Publishers, Siena: 1017-1022.

CANTRILL D. J. 1997b. - Hepatophytes from the early Cretaceous of Alexander Island, Antarctica: systematics and paleoecology. International Journal of Plant Sciences 158: 476-488. https:// doi.org/10.1086/297458

CANTRILl D. J. 2000. —A Cretaceous (Aptian) flora from President Head, Snow Island, Antarctica. Palaeontographica B 253: 153-191.

Chatterjee S., Goswami A. \& Scotese C. R. 2013. - The longest voyage: Tectonic, magmatic, and paleoclimatic evolution of the Indian plate during its northward flight from Gondwana to Asia. Gondwana Research 23: 238-267. https://doi.org/10.1016/J. GR.2012.07.001

Chinnappa C. H. 2016. - Contribution to Plant Ecosystem of Early Cretaceous Sequences of East Coast, India - Floral Diversification and Ecological Implications. PhD thesis, Andhra University, Visakhapatnam, Andhra Pradesh, India.

Chinnappa C. H. \& Rajanikanth A. 2017. — Early Cretaceous flora from the Pranhita-Godavari Basin (east coast of India): taxonomic, taphonomic and palaeoecological considerations. Acta Palaeobotanica 57 (1): 13-32. https://doi.org/10.1515/ acpa-2017-0005
Chinnappa C. H., Rajanikanth A. \& RaO Y. V. 2014. - Gymnosperm fossils from the Gangapur Formation (early Cretaceous), of Adilabad District, Telangana. Geophytology 44: 91-104.

Chinnappa C. H., Rajanikanth A. \& RaO Y. V. 2015. — Early Cretaceous plant diversity and Ecology in the Krishna-Godavari Basin, East Coast of India. Journal of the Palaeontological Society of India 60: 73-96.

Cleal C. J. \& ReEs P. M. 2003. — The Middle Jurassic flora from Stonesfield, Oxfordshire, UK. Palaeontology 46: 739-801. https:// doi.org/10.1111/1475-4983.00319

Couper R. A. 1955. - Supposedly colpate pollen grains from the Jurassic. Geological Magazine 92 (7): 471-474. https://doi. org/10.1017/S0016756800064633

DetTMann M. E. 1963. — Upper Mesozoic microfloras from southeastern Australia. Proceedings of the Royal Society of Victoria: 1-152.

Dettmann M. E. \& Playford G. 1969. - Palynology of the Australian Cretaceous: a review, in CAmpbell K. S. W. (ed.), Stratigraphy and Palaeontology: Essays in Honor of Dorothy Hill. Australian University press, Canberr: 174-210.

Doyle J. A., Jardiné S. \& Doerenkamp A. 1982. — Afropollis, a new genus of early angiosperm pollen, with notes on the Cretaceous palynostratigraphy and paleoenvironments of northern Gondwana. Bulletin des Centres de Recherches Exploration-Production Elf-Aquitaine 6: 39-117.

Drinnan A. N. \& Chambers T. C. 1986. - Flora of the Lower Cretaceous Koonwarra Fossil Bed (Korumburra Group), South Gippsland, Victoria. Memoirs of the Association of Australasian Palaeontologists 3: 1-77.

Feild T. S., Arens N. C., Doyle J. A., Dawson T. E. \& DonoGHUE M. J. 2004. - Dark and disturbed: a new image of early angiosperm ecology. Paleobiology 30: 82-107. https://doi. org/10.1666/0094-8373(2004)030<0082:DADANI>2.0.CO;2

Feild T. S., Chatelet D. S. \& Brodribb T. J. 2009. - Ancestral xerophobia: a hypothesis on the whole plant ecophysiology of early angiosperms. Geobiology 7: 237-264. https://doi. org/10.1111/j.1472-4669.2009.00189.x

FeistMantel O. 1876. - Jurassic (Liassic) flora of rhe Rajmahal Group for Golapili (near Ellore), Sourh Godavari District. Memoirs of the Geological Survey of India, Palaeontologia Indica series 2 (10): 163-233.

Feistmantel O. 1877. - Notes on fossil floras in India. Records of the Geological Survey of India 10 (4): 196. https://biodiversitylibrary.org/page/55847510

FeistMANTEL O. 1879. - The fossil flora of Upper Gondwanas, Outliers on the Madras Coast. Memoirs of the Geological Survey of India, Palaeontologia Indica Series 2: 191-224.

FeISTMANTEL O. 1882. - Fossil flora of Gondwana System in India-1. The fossil flora of the South Rewah Gondwana Basin. Memoirs of the Geological Survey of India, Palaeontologia Indica Series 12, 4 (1): 1-52.

FERGUSON D. K. 1985. - The origin of leaf-assemblages-new light on an old problem. Review of Palaeobotany and Palynology 46: 539-559. https://doi.org/10.1016/0034-6667(85)90041-7

Field T. S., Arens N. C., Doyle J. A., Dawson T. E. \& DonoGHUE M. J. 2004. - Dark and disturbed: a new image of early angiosperm ecology. Paleobiology 30: 82-107. https://doi. org/10.1666/0094-8373(2004)030<0082:DADANI>2.0.CO;2

FriIs E. M., CRANe P. R. \& PEDERSEN K. R. 2011. - Early Flowers and Angiosperm Evolution. Cambridge University Press, Cambridge, 596 p. https://doi.org/10.1017/CBO9780511980206

GASTALDO R. A. 1988. — Conspectus of phytotaphonomy. Methods and applications of plant paleoecology: notes for a short course. Paleontological Society Special Publication 3: 14-28. https://doi. org/10.1017/S247526220000486X

GASTALDO R. A. 1992. - Taphonomic considerations for plant evolutionary investigations. Palaeobotanist 41: 211-223.

GreENWOOD D. R. 1991. - The taphonomy of plant macrofossils, in Donovan S. K. (ed.), The Processes of Fossilization. Belhaven Press, London: 141-169. 
Harris T. M. 1961. — The Yorkshire Jurassic Flora. I. Thallophyta-Pteridophyta. British Museum of Natural History, London, 212 p. https://doi.org/10.5962/bhl.title.118957

Harris T. M. 1964. — The Yorkshire Jurassic Flora. II. Caytoniales, Cycadales \& Pteridosperms. British Museum of Natural History, London, 191 p. https://doi.org/10.5962/bhl.title.118957

HarRis T. M. 1969. - The Yorkshire Jurassic Flora. III. Bennettitales. British Museum of Natural History, London, 86 p. https://doi. org/10.5962/bhl.title.118957

HARRIS T. M. 1979. - The Yorkshire Jurassic Flora. V. Coniferales. British Museum of Natural History, London, 167 p.

Harris T. M. \& Millington W. 1974. - The Yorkshire Jurassic Flora. IV. Ginkgoales. British Museum of Natural History, London, 78 p. https://doi.org/10.5962/bhl.title.118957

HiLl R. S. 1994. - History of the Australian Vegetation: Cretaceous to Recent. Cambridge University Press, Cambridge, 443 p. https:// doi.org/10.20851/australian-vegetation

JAIN K. P. 1968. — Some plant remains from the Upper Gondwana of East Coast, India. Palaeobotanist 16: 151-154.

Jeyasingh D. E. P. \& Kumarasamy D. 1994. - Occurrence of Pityospermum Nathorst in the Sriperumbudur Formation, Tamil Nadu. Current Science 67: 305.

KAR R. K. \& SAH S. C. D. 1970. - Palynological investigation of the Gondwana outcrop from Vemavaram with remarks on the age of the beds. Palaeobotanist 18: 103-117.

KendalL M. W. 1949. - On a new conifer from the Scottish Lias. Annals and Magazine of Natural History 12 (2): 299-308. https:// doi.org/10.1080/00222934908653989

KING W. 1880. - Upper Gondwana and other formations of the Godavari district. Memoirs of the Geological Survey of India 16: 195-252.

Krassilov V. A. 1975. - Paleoecology of Terrestrial Plants: Basic Principles and Techniques. John Willey and Sons, New York, 283 p.

Kustatscher E., Van Konijnenburg-Van Cittert J. H. A. \& RogHI G. 2010. - Macrofloras and palynomorphs as possible proxies for palaeoclimatic and palaeoecological studies: A case study from the Pelsonian (Middle Triassic) of Kühwiesenkopf/ Monte Prà della Vacca (Olang Dolomites, N-Italy). Palaeogeography, Palaeoclimatology, Palaeoecology 290: 71-80. https://doi. org/10.1016/j.palaeo.2009.07.001

LAKSHMINARAYANA G. 2002. - Evolution in basin fill style during the Mesozoic Gondwana continental break-up in the Godavari Triple junction, S. E. India. Gondwana Research 5: 227-244. https://doi.org/10.1016/S1342-937X(05)70906-0

LaKshminarayana G., Murti K. S. \& RaO M. R. 1992. — Stratigraphy of Upper Gondwana sediments in the Krishna-Godavari coastal tract, Andhra Pradesh. Journal of the Geological Society of India 39: 39-49.

Lal N. K., Siawal A. \& Kaul A. K. 2009. - Evolution of East Coast of India-A plate tectonic reconstruction. Journal of the Geological Society of India 73: 249-260. https://doi.org/10.1007/ s12594-009-0081-1

LELE K. M. 1962. - Studies in the Indian Middle Gondwana Flora-1. On Dicroidium from the Sowth Rewa Gondwana Basin. Palaeobotanist 10: 48-68.

Mahabale T. S. \& Satyanarayana T. 1979. - Upper Gondwana plant fossils from East Godavari District in Andhra Pradesh, India. Geophytology 9: 65-82.

Maheshwari H. K. \& Jana B. N. 2004. - Spores and pollen of the Ptilophyllum Flora in Kutch Basin, India, in SRIVASTAVA P. C. (ed.), Vistas in Palaeobotany and Plant Morphology: Evolutionary and Environmental Perspectives. Prof. D. D. Pant Memorial Volume. U.P. offset, Lucknow, India: 207-219.

McLoughlin S. 1996. - Early Cretaceous macrofloras of Western Australia. Records of Western Australia Museum 18: 19-65.

MCLoughlin S. 2001. - The breakup history of Gondwana and its impact on pre-Cenozoic floristic provincialism. Australian Journal of Botany 49: 271-300. https://doi.org/10.1071/ BT00023
Mcloughlin S., Tosolini M. P., Nagalingum N. \& Drinnan A. N. 2002. - The early Cretaceous (Neocomian) flora and fauna of the lower Strzelecki Group, Gippsland Basin, Victoria, Australia. Memoir Association Australasian Palaeontology 26: 1-144. https://doi.org/10.1080/03115510208619239

Mehrotra N. C., Venkatachala B. S. \& Kapoor P. N. 2010. Palynology in hydrocarbon Exploration: high Impact Palynological studies in western Offshore and Krishna-Godavari basins. Journal of the Geological Society of India 75 (2): 364-379. https://doi.org/10.1007/s12594-010-0032-x

Mehrotra N. C., Shanmukhappa M., Babu R., Kumar M., SingH A., SingH B. D. \& KAPOOR P. N. 2012. - Development of palynology in fossil fuel exploration in India with emphasis on recent significant contribution from Western-Offshore, Krishna-Godavari Basin and Frontier areas. Proceedings of Indian National Science Academy 78: 457-473.

NaugolnykH S. V. 2002. - A new species of Todites (Pteridophyta) with in situ spores from the Upper Permian of Pechora Cis-Urals (Russia). Acta Palaeontologica Polonica 47 (3): 469-478.

Pandya N. \& SuKH-DeV 1990. - Fossil flora of Gollapalli Formation. Palaeobotanist 38: 147-154.

Pandya N., SRivastava V. B. \& Sukh-Dev 1990. - A new conifer fossil from Vemavaram (Early Cretaceous), Andhra Pradesh, India. Geophytology 20: 74.

Pant D. D., SRivastava G. K. \& Pant R. 1983. - On the cuticular structure of leaves of Desmiophyllum type from Bansa beds of India and their assignment to the genus Harrisiophyllum gen. nov. Palaeontographica B 185: 38-55.

Pelzer G., Riegel W. \& Wilde V. 1992. - Depositional controls on the Lower Cretaceous Wealden coals of northwest Germany. Geological Society of America Special Papers 267: 227-244. https://doi.org/10.1130/SPE267-p227

Pott C., Krings M. \& Kerp H. 2008. - The Carnian (Late Triassic) flora from Lunz in Lower Austria: Palaeoecological considerations. Palaeoworld 17: 172-182. https://doi. org/10.1016/j.palwor.2008.03.001

PotT C. \& LAUNIS A. 2015. - Taeniopteris novomundensis sp. nov. - "cycadophyte" foliage from the Carnian of Switzerland and Svalbard reconsidered: How to use Taeniopteris? Neues Jahrbuch für Geologie und Paläontologie 275: 19-31. https:// doi.org/10.1127/njgpa/2015/0446

PrabhaKar K. N. \& ZUTCHIN P. L. 1993. - Evolution of southern part of Indian East Coast basins. Journal of the Geological Society of India 41: 215-230.

PRASAD B. \& PUNDIR B. S. 1999. - Biostratigraphy of the exposed Gondwana and Cretaceous rocks of Krishna-Godavari basin, India. Journal of the Palaeontogical Society of India 44: 91-117.

RajanikANTH A. \& SuKH-Dev 1989. - The Kota Formation: fossil flora and stratigraphy. Geophytology 19: 52-64.

RAJANIKANTH A. \& CHINNAPPA C. H. 2016. - Early Cretaceous flora of India-A review. Palaeobotanist 65: 209-245.

Rajeshwar Rao P. V. \& Ramanujam C. G. K. 1979. - The genus Contignisporites from the Lower Cretaceous, Gangapur beds of Adilabad District, A. P. Geophytology 9: 139-143.

Raju D. S. N. \& MisRa P. K. 1996. - Cretaceous Stratigraphy of India-A review. Memoirs of the Geological Society of India 37: 1-33.

Ramanujam C. G. K. 1957. — Microfossils from carbonaceous shale near Vemavaram (Jurassic) in the East Coast Gondwanas of India. Journal of Indian Botanical Society 36: 181-197.

Ramanujam C. G. K. 1980. - Geological history of Araucariaceae in India. Botanique 9: 1-2.

Ramanujam C. G. K. \& Rajeshwara Rao P. V. 1979. - Palynological approach to the study of some Upper Gondwana clays at Ralpet near Asifabad in Adilabad District of Andhra Pradesh. Geological Survey of India, Miscellaneous Publication 50: 45-60.

Rangaraju M. K., Aggarwal A. \& PrabhaKar K. N. 1993. Tectono-stratigraphy, structural styles, evolutionary model and hydrocarbon prospects of Cauvery and Palar Basins, India. Pro- 
ceedings of the Second Seminar on Petroliferous Basins of India, Dehra Dun: 331-354.

RAO A. R. \& LELE K. M. 1963. — On the cuticle of Dicroidium (Thinnfeldia) Sahnii (Seward) with some observations on the genera Thinnfeldia and Dicroidium. Palaeobotanist 11: 7-12.

RAO G. N. 2001. - Sedimentation, stratigraphy and petroleum potential of Krishna-Godavari Basin, East Coast of India. AAPG Bulletin 85 (9): 1623-1643. https://doi.org/10.1306/8626CCDF173B-11D7-8645000102C1865D

RAO G. N. 1993. - Geology and hydrocarbon prospects of East Coast sedimentary basins of India with special reference to Krishna-Godavari Basin. Journal of the Geological Society of India 41: 444-454.

RaO V. R. \& Venkatachala B. S. 1972. - Upper Gondwana marine intercalations in peninsular India. Annals of Geology Department, Aligarh Muslim University (5-6): 353-389.

READER R. J. \& STEWART J. M. 1972. - The relationship between net primary production and accumulation for a peatland in southeastern Manitoba. Ecology 53: 1024-1037. https://doi. org/10.2307/1935415

RoYer D. L., Hickey L. J. \& Wing S. L. 2003. — Ecological conservatism in the "living fossil" Ginkgo. Paleobiology 29: 84-104. https://doi.org/10.1666/0094-8373(2003)029<0084:ECITL $\mathrm{F}>2.0 . \mathrm{CO} ; 2$

SAHNI B. 1928. - Revisions of Indian fossil plants Pt. 1 Coniferales (a. impressions \& incrustations). Memoirs of the Geological Survey of India, Palaeontologia Indica, new series 11: 1-49.

SAHNI B. 1931. - Revision of Indian fossil plants: Parts II-Coniferales (b. Petrifications). Memoirs of the Geological Survey of India, Palaeontologia Indica, new series 11: 51-124.

SAJJADI F. \& PLAYFORD B. 2002a. - Systematic and stratigraphy of late Jurassic-Earliest Cretaceous strata of the Euromenga Basin, Queensland, Antarctica. Part One. Palaeontographica B 261: 1-97.

SAJJADI F. \& PLAYFORD B. 2002b. - Systematic and stratigraphy of late Jurassic-earliest Cretaceous strata of the Euromenga Basin, Queensland, Antarctica. Part Two. Palaeontographica B 261: 99-165.

SASTRI V. V., Sinha R. N., Singh G. \& MurThy K. V. S. 1973. Stratigraphy and tectonics of the sedimentary basins on East Coast of Peninsular India. American Association of Petroleum Geology Bulletin 574: 655-678.

Sastri V. V., Venkatachala B. S. \& Narayanan V. 1981. - The evolution of the East Coast of India. Palaeogeography Palaeoclimatology Palaeoecology 36: 23-54. https://doi.org/10.1016/00310182(81)90047-X

SCHRANK E. 2010. - Pollen and spores from the Tendaguru Beds, Upper Jurassic and Lower Cretaceous of southeast Tanzania: palynostratigraphical and paleoecological implications. Palynology 34: 3-42. https://doi.org/10.1080/01916121003620106

SCOTESE C. R. 2000. - Paleomap project. Climate history. http:// www.scotese.com/climate.htm (last consultation on 9 May 2018)

SEWARD A. C. 1919. - Fossil Plants: for Students of Botany and Geology. Vol. 4. Hafner Publications Company, New York, 543 p. https://doi.org/10.5962/bhl.title.54901

SEWARD A. C. \& SAHNi B. 1920. - Indian Gondwana plants: a revision. Memoirs of the Geological Survey of India, Palaeontologia indica, new series 7: 1-41.

SPATH L. F. 1933. - Revision of the Cephalopod fauna of Cutch. Memoirs of the Geological Survey of India, Palaeontologia indica, new series 9: 659-945.

SPICER R. A. 1991. - Plant taphonomic processes, in AluISON P. A. \& BRiggs D. E. G. (eds), Taphonomy Releasing the Data Locked in the Fossil Record - Topics in Palaeobotany. Plenum Press, New York: 74-111.

Spicer R. A. \& Greer A. G. 1986. - Plant taphonomy in fluvial and lacustrine systems, in BROADHEAD T. W. (ed.), Land Plants Notes for a Short Course. University of Tennessee, Department of Geological Science, Studies in Geology 15: (10-26).

Spicer R. A., ReEs P. M. \& Chapman J. L. 1994. - Cretaceous phytogeography and climate signals. Palaeoclimates and their Modeling 69: 78 p. https://10.1007/978-94-011-1254-3

SRIVASTAVA S. K. 1976. - The fossil pollen genus Classopollis. Lethaia 9 (4): 437-457. https://doi.org/10.1111/j.1502-3931.1976.tb00985.x Sun G., Ji Q., Dilcher D. L., Zheng S., NixON K. C. \& WANG X. 2002. - Archaefructaceae, a new basal Angiosperm family. Science 296: 899-904. https://doi.org/10.1126/science.1069439

TAYLOR D. W. \& HiCKEY L. J. 1996. - Evidence for and implications of a herbaceous origin for Angiosperms, in TAYLOR D. W. \& Hickey L. J. (eds), Flowering Plant Origin, Evolution, and Phylogeny. Chapman and Hall, New York: 232-266.

TIDWELL W. D. \& AsH S. R. 1994. - A review of selected Triassic to Early Cretaceous Ferns. Journal of Plant Research 107: 412442. https://doi.org/10.1007/BF02344066

Tosolini A. M. P., Mcloughlin S., Wagstaff B. E., Cantrill D. J. \& Gallagher S. J. 2013. - Cheirolepidiacean foliage and pollen from Cretaceous high-latitudes of southeastern Australia. Gondwana Research 27: 960-977. https://doi.org/10.1016/j. gr.2013.11.008

TownROW J. A. 1957. - On Dicroidium, probably a pteridospermous leaf and other leaves now removed from the genus. Transactions of the Geological Society of South Africa 60: 21-56. https://hdl.handle.net/10520/AJA10120750_2230

TRALAU H. 1967. - The phytogeographic evolution of the genus Ginkgo L. Botaniska notiser 120: 409-422.

Truswell E. M., Dettmann M. E. \& O’Brien P. E. 1999. — Mesozoic palynofloras from the Mac. Robertson shelf, East Antarctica: geological and phytogeographic implications. Antarctic Science 11: 239-255. https://doi.org/10.1017/S0954102099000309

VAGYANI B. A. 1984. - On the occurrence of Desmiophyllum indicum Sahni from Vemavaram. Proceedings of $5^{\text {th }}$ Indian Geophytological Conference, Paleobotanical Society, Lucknow, 362 p.

VAGYANI B. A. 1985. - Occurrence of Ginkgoites crassipes (Feistmantel) Seward from the Jurassic of Andhra Pradesh. Current Science 54: 705-706

Vagyani B. A. \& Jamane M. R. 1988. - Genus Dictyozamites Oldham from Uppugunduru, Prakasam District, Andhra Pradesh. Geophytology 18: 87.

Vagyani B. A. \& Zutting M. P. 1986. - Occurrence of Pterophyllum distans Morris from Uppugunduru, Andhra Pradesh. Geophytology 16: 133.

VAKHRAMEEV V. A. 1991. - Jurassic and Cretaceous Floras and Climates of the Earth. Cambridge University Press, Cambridge, 340 p.

Van Konijnenburg-Van Cittert J. H., Pott C., Cleal C. J. \& ZijLSTRA G. 2017. - Differentiation of the fossil leaves assigned to Taeniopteris, Nilssoniopteris and Nilssonia with a comparison to similar genera. Review of Palaeobotany and Palynology 237: 100-106. https://doi.org/10.1016/j.revpalbo.2016.11.009

VAN KoniJnEnBURG-VAN CitTERT J. H. A. 2002. - Ecology of some late Triassic to early Cretaceous ferns in Eurasia. Review of Palaeobotany and Palynology 119: 113-124. https://doi.org/10.1016/ S0034-6667(01)00132-4

VasudeVA RaO P. \& KRISHNa RaO V. V. 1977. — Stratigraphy, basin framework, sedimentation structures and petroleum prospects of the Gondwanas of Godavari graben. Proceedings of IV Gondwana: 25-30.

VenKatachala B. S. 1966. - Mesozoic operculate pollen and their morphology. Palaeobotanist 15: 98-101.

VenKatACHALA B. S. \& RAJANiKANTH A. 1987. — Stratigraphic implication of "late Gondwana" floras in the East Coast. Palaeobotanist 36: 183-196.

Venkatachala B. S. \& Sinha R. N. 1986. - Stratigraphy, age and palaeoecology of Upper Gondwana equivalents of the Krishna-Godavari Basin, India. Palaeobotanist 35: 22-31.

Villar De SeOANe L. 2001. - Cuticular study of Bennettitales from the Springhill Formation, Lower Cretaceous of Patagonia, Argentina. Cretaceous Research 22: 461-479. https://doi. org/10.1006/cres.2001.0266 
Watson J. \& Alvin K. L. 1996. — An English Wealden floral list, with comments on possible environmental indicators. Cretaceous Research 17 (1): 5-26. https://doi.org/10.1006/cres.1996.0002 WATSON J. \& SinCOCK C. A. 1992. - Bennettitales of the English Wealden. Monograph of the Palaeontographical Society 145: 1-228.

Wright I. J., Reich P. B., Cornelissen J. H., Falster D. S., Groom P. K., Hikosaka K., LeE W., Lusk C. H., Ninnemets Ü., Oleksyn J., Osada N., Poorter H., Warton D. I. \& Westoby M. 2005. - Modulation of leaf economic traits and trait relationships by climate. Global Ecology and Biogeography 14 (5): 411-421. https://doi.org/10.1111/j.1466-822x.2005.00172.x ZHOU Z. Y. 2009. - An overview of fossil Ginkgoales. Palaeoworld 18: 1-22. https://doi.org/10.1016/j.palwor.2009.01.001

Ziegler A. M., Rees P. M., Rowley D. B., BeKker A., Qing L. \& Hulver M. L. 1996. - Mesozoic assembly of Asia: constraints from fossil floras, tectonics, and paleomagnetism, in YIN A. \& Harrison M. (eds), The Tectonic Evolution of Asia. Cambridge University Press, Cambridge: 371-400. 
APPENDIX 1. - List of the macroflora reported from the Krishana-Godavri Basin.

\section{PTERIDOPHYTES}

Cladophlebis medlicottiana (Oldham) Pascoe, 1959

C. polypodioides Brongniart, 1849

Cladophlebis cf. longipennis Seward, 1925

Cladophlebis sp.

Gleichenia bosahii (Bose) Pant \& Srivastava, 1977

G. nordenskioeldii Heer, 1874

Marattiopsis macrocarpa (Oldham \& Morris) Seward \& Sahni, 1920

Onychiopsis cf. psilotoides (Stopes \& Web) Ward, 1905

Todites indicus (Oldham \& Morris) Bose \& Sah, 1968

Sphenopteris specifica (Feistmantel) Roy, 1968

Sphenopteris sp.

\section{GYMNOSPERMS}

\section{PTERIDOSPERMS}

Thinnfeldia vemavaramensis (Feistmantel) Chinnappa, Rajanikanth \& Rao, 2015

Pachypteris indica (Oldham \& Morris) Bose \& Roy, 1968

\section{CyCADALEANS}

Taeniopteris spatulata (McClelland) Bose \& Banerji, 1981

Taeniopteris sp.

\section{BENNETTITALEANS}

Anomozamites sp.

Cycadolepis indica Gupta, 1954

Cycadolepis sp.

Dictyozamites falcatus Medlicott \& Banford, 1879

D. feistmantelii Bose \& Bano, 1978

D. hallei Sahni \& Rao, 1933

D. indicus Feistmantel, 1876

D. ommevaramensis Chinnappa, Rajanikanth \& Rao, 2014

D. sahnii Gupta \& Sharma, 1968

Otozamites acutifolius Feistmantel, 1879

O. bengalensis Schimper, 1870

O. exhislopi Bose, 1974

O. gondwanensis Bose, 1974

O. imbricatus Feistmantel, 1879

O. vemavaramensis Bose \& Jain, 1967

Otozamites sp.

Pterophyllum footeanum Feistmantel, 1879

P. incisum Sahni \& Rao, 1933

P. kingianum Feistmantel, 1877

Pterophyllum sp.

Ptilophyllum acutifolium (Morris) Bose \& Kasat, 1972

P. cutchense (Morris) Bose \& Kasat, 1972

P. deodikarii Mahabale \& Satyanarayana, 1979
BENNETTITALEANS (continuation)

Ptilophyllum heterophylla Chinnappa, Rajanikanth \& Rao, 2014

P. rarinervis (Feistmantel) Bose \& Kasat, 1972

P. tenerrimum (Feistmantel) Bose \& Kasat, 1972

Ptilophyllum cf. distans (Feistmantel) Bose \& Kasat, 1972

Ptilophyllum cf. institacallum Bose, 1959

Ptilophyllum cf. amarjolense Bose, 1953

Ptilophyllum cf. gladiatum Bose \& Sukh-Dev, 1958

Ptilophyllum cf. horridum Roy, 1963

Ptilophyllum cf. jabalpurense Jacob \& Jacob, 1954

Williamsonia blandfordii Feistmantel, 1876

W. indica Seward, 1917

GINKGOALEANS

Ginkgo crassipes (Feistmantel) Chinnappa, 2016

G. feistmantelii (Bose \& Sukh-Dev) Chinnappa, 2016

Ginkgo sp. A

Ginkgo sp.

\section{Coniferaleans}

Araucarites cutchensis Feistmantel, 1877

A. fibrosa Sukh-Dev \& Bose, 1972

A. macropteris Feistmantel, 1877

A. minutus Bose \& Maheshwari, 1973

Brachyphyllum expansum (Sternberg) Seward, 1904

B. feistmantelii (Halle) Sahni, 1928

B. regularis Borkar \& Chiplonkar, 1973

B. rhombicum Feistmantel, 1879

B. sehoraensis Bose \& Maheshwari, 1973

Brachyphyllum sp.

Conites sessilis Sahni, 1928

Conites sp.

Elatocladus confertus Seward \& Sahni, 1920

E. jabalpurensis (Feistmantel) Sahni, 1928

E. loyolii Chinnappa, Rajanikanth \& Rao, 2014

E. plana (Feistmantel) Seward, 1919

E. tenerrimus (Feistmantel) Sahni, 1928

E. vemavaramensis Pandya Pandya, Srivastava \& Sukh-Dev, 1990

Elatocladus sp.

Harrisiophyllum hacketioides Pant, Srivastava \& Pant, 1983

Pagiophyllum feistmantelii Halle, 1913

P. gollapallensis Pandya \& Sukh-Dev, 1990

Pagiophyllum cf. grantii Bose \& Banerji, 1984

Pagiophyllum cf. marwarensis Bose \& Sukh-Dev, 1972

P. ommevaramensis Chinnappa, Rajanikanth \& Rao, 2014

Pagiophyllum sp.

Pityospermum godavarianum Chinnappa, Rajanikanth \& Rao, 2015

Torreyites constricta (Feistmantel) Seward \& Sahni, 1920 


\section{BRYOPHYTES}

Foraminisporis dailyi Dettmann, 1963

F. wonthaggiensis Dettmann, 1963

Coronatispora sp.

Aequitriradites spinulosus Cookson \& Dettmann, 1961

Coptospora cauveriana Venkatachala, 1973

Cooksonites variabilis Pocock, 1962

Staplinisporites caminus Pocock, 1962

\section{PTERIDOPHYTES}

Alsophyllidites grandis Sah \& Jain, 1965

Appendicisporites sellingii Pocock, 1964

Baculatisporites comaumensis Potonié, 1953

B. baculatus Krutzsch, 1959

Biretisporites potoniae Delcourt \& Sprumont, 1955

Ceratosporites equalis Cookson \& Dettmann, 1958

Cicatricosisporites australiensis Potonié, 1956

C. hughesii Dettmann, 1963

C. lodbrokiae Dettmann, 1963

Cicatricosisporites sp.

Conbaculatisporites densibaculatus Sharma, Jain \& Venkatachala, 1977

Concavissimisporites punctatus Pocock, 1964

C. variverrucatus Brenner, 1963

Concavissimisporites sp.

Contignisporites cooksoniae Dettmann, 1963

C. glebulentus Dettmann, 1963

C. multimuratus Dettmann, 1963

Contignisporites sp.

Crybelosporites punctatus Dettmann, 1963

C. striatus Dettmann, 1963

C. stylosus Dettmann, 1963

Crybelosporites sp.

Cyatheacidites tectifera Archangelsky \& Gamerro, 1965

Cyathidites asper Dettmann, 1963

C. australis Couper, 1953

C. cutchensis Singh, Srivastava \& Roy, 1964

C. jurassicus Kar \& Sah, 1970

C. minor Couper, 1953

C. pseudopunctatus Singh, Srivastava \& Roy, 1964

C. punctatus Delcourt, Dettmann \& Hughes, 1963

C. rajmahalensis Sah \& Jain, 1964

C. trilobatus Sah \& Jain, 1964

Cyathidites sp.

Deltoidospora diaphana Wilson \& Webster, 1946

D. juncta Singh, 1964

Densoisporites microregulatus Brenner, 1963

D. velatus Dettmann, 1963

Dictyophyllidites harrisii Couper, 1958

Gleichinidites circinidites (Cookson) Dettmann, 1963

G. senonicus Dettmann, 1963

Impardecispora purverulenta (Verbitzkaya) Venkatachala, Kar \& Raza, 1969

I. trireticulosa Venkatachala, Kar \& Raza, 1969

I. tribotrys (Dettmann) Venkatachala, Kar \& Raza, 1969

\section{PTERIDOPHYTES (CONTINUATION) \\ Impardecispora sp.}

Ischyosporites punctatus Cookson \& Dettmann, 1958

Ischyosporites $\mathrm{sp}$.

Klukisporites foveolatus Pocock, 1965

K. scaberis Dettmann, 1963

Laevigataletes sp.

Laevigatazonaletes sp.

Laevigatimonoletes $\mathrm{sp}$.

Laevigatisporites sp.

Leptolepidites major Couper, 1953

L. verrucatus Couper, 1953

Leptolepidites sp.

Liratosporites sp.

Lycopodiumsporites crassimacerius Hedlund, 1966

L. eminulus Dettmann, 1963

L. regulatus Semenova, 1970

L. reticulum Venkatachala \& Kar, 1968

L. reticulumsporites Dettmann, 1963

Lycopodiumsporites sp.

Matonisporites sp.

Murospora florida Pocock, 1961

Neoraistrickia truncatus Potonié, 1956

Ornamentifera granulosa Sharma, Jain \& Venkatachala, 1977

Ornamentifera sp.

Osmundacidites wellmanii Couper, 1953

Plicifera senonicus (Ross) Bolkhovitina, 1966

Polycingulatisporites reduncus Playford \& Dettmann, 1965

Reticulatazonalesporites sp.

Reticulatisporites sp.

Retitriletes austroclavatidites (Cookson) Krutzsch, 1963

$R$. circolumenus Backhouse, 1978

R. eminulus Srivastava, 1975

Sestrosporites pseudoalveolatus Dettmann, 1963

Striatella balmei Filatoff \& Price, 1988

Taurocusporites segmentatus Stover, 1962

Thymospora sp.

Todisporites minor Couper, 1953

Triletes verrucosus Faddeeva, 1965

Triletes sp. 
APPENDIX 2 (continuation). - List of the microflora reported from the Krishana-Godavri Basin.

\section{GyMnOSPERMS}

Abietineaepollenites ellipticus Kar \& Sah, 1970

A. robustus Kar \& Sah, 1970

Alisporites grandis Dettmann, 1963

Alisporites sp.

Araucariacites australis (Cookson, 1947) Cooper, 1953

A. indicus Sukh-Dev, 1961

Callialasporites dampieri Sukh Dev, 1961

C. monoalasporus Sukh Dev, 1961

C. segmentatus Srivastava, 1963

C. triletus Singh, Srivastava et Roy, 1964

C. trilobatus Sukh Dev, 1961

Callialasporites sp.

Cedripites cretaceus Pocock, 1962

C. nudis Kar \& Sah, 1970

Classopollis classoides Fensome, 1983

C. torosus Burger, 1965

Entylissa sp.

Florinites sp.

Ginkgocycadophytus srivastavae Kar \& Sah, 1970

G. nitidus Venkatachala, 1969

Granuloperculatipollis flavatus Kar, 1970

G. subcircularis Kar \& Sah, 1970

G. triletus Kar \& Sah, 1970

Indusiisporites microsaccatus Kar \& Sah, 1970

Laricoidites indicus Singh, Srivastava \& Roy, 1964

Microcachrydites antarcticus Couper, 1953

Pityosporites sp.

Platysaccus sp.

Podocarpidites alareticulosus Sah \& Jain, 1965

P. cristiexinus Sah \& Jain, 1965

P. ellipticus Cookson, 1947

P. grandis Sah, 1965

P. multisimus (Bolkhovitina) Pocock. Venkatachala, Kar \&

Raza, 1969

P. rarus Singh, Srivastava \& Roy, 1964

P. typicus Sah, 1965

Podocarpidites sp.

Podosporites raoi Singh, Srivastava \& Roy, 1964

P. tripakshii Rao, 1943

Podosporites sp.

\section{ANGIOSPERMS}

Asteropollis asteroides Hedlund \& Norris, 1968

Clavatipollenites hughesii Couper, 1958

Clavatricolporites leticiae Leidelmeyer, 1966

Liliacidites reticulatus Doyle, 1975

Polybrevicolpites sp.

Polycolpites sp.

Racemonocolpites facilis González-Guzmán. 1967

R. ramonus González-Guzmán. 1967

Rousea georgensis Dettmann, 1973

Spinizonocolpites echinatus Muller, 1968

Tricolpites georgensis (Brenner) Dettmann, 1973

Tubulifloridites lilleie (Couper) Farabee \& Canright, 1986

Turonipollis helmegii Van Ameron, 1975

\section{INCERTAE SEDIS}

Apiculatasporites sp.

Apiculatimonoletes sp.

Apicultaletes sp.

Bhujiasporites sp.

Complexiopollis complicatus Góczán, 1964

Coniatisporites telata Singh, 1972

Dictyotosporites complex Cookson \& Dettmann, 1958

Dictyotosporites speciosus Cookson \& Dettmann 1958

Erdtmannipollis sp.

Odontochitina operculata Deflandre \& Cookson, 1955

Periplecosporites sp.

Ramanujamiaspora reticulata Ramanujam, 1957

Regulatisporites sp.

Setosisporites sp.

Singhipollis rudis Kar \& Sah, 1970

Singhipollis triletus Singh, Srivastava \& Roy, 1964

Striatotuberculatisporites sp. 